\title{
Blended learning, e-learning and mobile learning in mathematics education
}

\author{
Marcelo C. Borba ${ }^{1} \cdot$ Petek Askar $^{2} \cdot$ Johann Engelbrecht $^{3} \cdot$ George Gadanidis $^{4}$. \\ Salvador Llinares ${ }^{5}$ Mario Sánchez Aguilar ${ }^{6}$ (D)
}

Accepted: 14 June 2016 / Published online: 28 June 2016

(C) FIZ Karlsruhe 2016

\begin{abstract}
In this literature survey we focus on identifying recent advances in research on digital technology in the field of mathematics education. To conduct the survey we have used internet search engines with keywords related to mathematics education and digital technology and have reviewed some of the main international journals, including the ones in Portuguese and Spanish. We identify five sub-areas of research, important trends of development, and illustrate them using case studies: mobile technologies, massive open online courses (MOOCs), digital libraries and designing learning objects, collaborative learning using digital technology, and teacher training using blended learning. These examples of case studies may help the reader to understand how recent developments in this area of research have evolved in the last few years. We conclude the report discussing some of the implications that these digital technologies may have for mathematics education research and practice as well as making some recommendations for future research in this area.
\end{abstract}

Mario Sánchez Aguilar

mosanchez@ipn.mx

Marcelo C. Borba

mborba@rc.unesp.br

Petek Askar

petek.askar@gmail.com

Johann Engelbrecht

Johann.Engelbrecht@up.ac.za

George Gadanidis

ggadanid@uwo.ca

Salvador Llinares

sllinares@ua.es

1 Graduate Program in Mathematics Education, UNESP, Rio Claro, Brazil
Keywords Internet · Mobile learning · MOOC . Blended learning $\cdot$ Digital libraries $\cdot$ Learning objects . Collaborative learning

\section{Introduction}

"Digital technology has changed the very notion of what being a human means."

Assertions such as the one above can be found in the literature at large. The idea that innovative media tools we use condition our thinking is not new and consequently should not be surprising. McLuhan (1964) determined this link several decades ago with his often-quoted assertion that "the medium is the message". Borba (2012) supports this statement, using examples from mathematics educational settings, which illustrate how these changes are being experienced in mathematics education. Mobility, online courses,

2 Emeritus, Department of Computer Education and Instructional Technology, Hacettepe University, Ankara, Turkey

3 Department of Science, Mathematics and Technology Education, University of Pretoria, Pretoria, South Africa

4 Faculty of Education, Western University, London, ON, Canada

5 Departamento de Innovación y Formación Didáctica, Facultad de Educación, Universidad de Alicante, Alicante, Spain

6 Programa de Matemática Educativa, CICATA Legaria, Instituto Politécnico Nacional, Calzada Legaria No. 694, Col. Irrigacion, Del. Miguel Hidalgo, C.P. 11500 Mexico City, Mexico 
massive open online courses (MOOCs) and touch technology are terms that are part of our lives as mathematics educators, and many of these terms are part of the daily lives of $45 \%$ of the world population that has access to the internet. This paper is about the digital technology that is available to almost half of the world population, but we assert that digital technology is also changing the lives of those people who do not have access to the internet- that social relationships are being shaped by this plastic technology (Levy 1993) that permeates almost everything we touch, even if we (with or without access) are not aware of it.

Research struggles to keep up with the pace of change in the world of digital technology. We like to determine identifiable phases in the development of using digital technology in mathematics education. The first phase commenced with the introduction of Logo as a teaching tool. Academics began to research its use and impact, but before we knew it, "content" software such as Cabri or Geometer's Sketchpad became available. We had not yet solved all the problems from this first phase of digital technology in mathematics education (Borba 2012; Borba et al. 2014), when the second phase arrived with new notions such as dragging, that allowed students to "experiment mathematics". Again, we were still trying to understand the role of computer laboratories in schools, a novelty from both the first and second phases (depending on the country), when the internet showed up.

We shift our focus from microworlds, to modelling, to computer laboratories, and now to the relationship revolution (Schrage 2001), afforded by online tools, which we refer to as the third phase. This phase, characterized by the internet, brings us communication changes that dramatically alter the way we relate to one another. This creates new research problems to be addressed (Engelbrecht and Harding 2005a, b; Borba et al. 2010; van de Sande 2011) and prompted us to include collaborative learning using technology as one of the current trends of development. In mathematics education, the way the internet can be used in a blended learning environment (a further development trend) characterizes the third phase, which introduces online courses and new problems.

Quantitative change in the internet has generated a change in quality, and expressions such as Web 2.0 and broadband internet indicate that a new internet has developed over the last 5-10 years. This new phase, which we are experiencing now and refer to as the fourth phase, brings us MOOCs-another trend of development, enhanced opportunities for collaborative learning, and the personalization of the internet through personal devices. It opens up the possibility that everyone with access to the internet can express her or himself digitally through different forms of multimodal discourse. This phase also opens new opportunities for storing digital information through the massive increases in storage and computing power, and the emergence of cloud computing; it is in this context that digital libraries appear as another trend of development. Along with these developments, a move to mobile technology introduces new possibilities in the teaching of mathematics and leads to a further prominent development trend, included in our discussion.

From the discussion above we see that five prominent trends of development were identified. In this paper we attempt to contribute to the goal of surveying this changing area in a particular way, in that we focus on these five important sub-areas of current research, reporting developments related to mobile technologies, MOOCs, digital libraries and designing learning objects, collaborative learning using digital technology, and teacher training using blended learning.

In each of these trends of development we included a case study as an example of the particular trend. Before discussing the different trends, we explain the method that was followed to locate the bibliographic information on which this survey study is based. We conclude the paper by discussing some of the implications that these digital technologies may have for mathematics education research and practice as well as making some recommendations for future research in this area.

\section{Methodology}

Several publications have attempted to survey this emerging and always-changing area of digital technologies in mathematics education. Eight chapters on digital technology in the Third International Handbook of Mathematics Education (Clements et al. 2013), and the special issue of ZDM on online distance education (Borba and Llinares 2012) are examples of such publications. These publications attempt to organize the field of research in order to do what Bicudo (2014) calls meta-analysis. This paper attempts to contribute to this goal of surveying this changing area in a particular way: it will focus on cases of what the authors believe are important trends of development at this moment. Particularly in this survey we focus on reporting developments related to mobile learning, MOOCs, digital libraries and learning objects, blended courses, and collaborative learning.

To develop the survey we relied on three sources of information: (1) international research journals, including journals in Portuguese and Spanish, (2) internet search engines with keywords related to mathematics education and digital technology and (3) the knowledge of the authors of this article about the surveyed areas.

Regarding the research journals consulted, we reviewed the issues published during the last 5 years in the journals 
positioned at levels $\mathrm{A}^{*}, \mathrm{~A}$ and $\mathrm{B}$ of the ranking produced by the Education Committee of the European Mathematical Society (Toerner and Arzarello 2012), namely, Educational Studies in Mathematics, Journal for Research in Mathematics Education, For the Learning of Mathematics, The Journal of Mathematical Behavior, Journal of Mathematics Teacher Education, Mathematical Thinking and Learning, ZDM-The International Journal on Mathematics Education, International Journal of Mathematical Education in Science and Technology, International Journal of Science and Mathematics Education, Mathematics Education Research Journal, Recherches en Didactique des Mathématiques, and Research in Mathematics Education. We also review the issues published during the last 5 years in the research journals that we consider most influential in Latin America: BOLEMA: Boletim de Educação Matemática, Revista Latinoamericana de Investigación en Matemática Educativa and Educación Matemática.

With regard to the search through internet search engines, we relied primarily on the use of Google (although the specialized database MathEduc was also used) in combination with the use of keywords related to mathematics education and digital technology such as "mobile learning mathematics education" or "MOOC mathematics education". As a result of this search not only specialized items were located but also websites.

Another source of information on which this survey was based was the knowledge of the authors of this paper about the areas under study. The authors helped to identify projects or initiatives related to mathematics and these digital technologies. This information was very useful especially in the case of areas in which not too many publications have been produced.

\section{Trends of development}

D'Ambrosio and Borba (2010) consider trends of development, such as the use of digital technology in mathematics education, as a response to problems within the region of inquiry in mathematics education. The constant concern in books, journals, and in conferences (such as ICME) in having various working groups and survey teams to map the research in this area, shows that this trend is still growing. But to what problem does this sub-area of investigation respond? It seems that all phases of attempts to introduce digital technology have faced problems related to displacing embedded rules of time and space that we were not aware of when we experienced the "paper-andpencil" classroom. As Schrage (2001) has pointed out, digital communication technology has created a "relationship revolution." If perceived this way, we will understand that notions such as the ones of humans-with-media emphasize that if media are changed, knowledge (understood not only as result, but as the whole process) may change. Moreover, as humans develop and construct new media, these media seem to transform and "construct" a new human.

In this paper, we consider how mathematics education is changing as the technology around us changes, and what the consequences of those changes might be. We do not intend to make a comprehensive survey of papers, even though we have highlighted a few in each of the chosen categories. We focus on describing five cases of mathematics education in which digital technology is used in different ways. We hope that examples of cases (or the lack thereof) may help the reader to understand how recent developments in this sub-area of research may have evolved in the last few years.

\subsection{Use of mobile technologies in mathematics teaching and learning}

The use of mobile technologies (such as smartphones and tablets) in the teaching and learning of mathematics is gaining a growing interest among educational researchers and practitioners. The characteristics of mobile devices such as portability, availability, access to the internet, and its wide acceptance among young people and others, have made mobile devices an emerging agent capable of expanding the frontiers of mathematics instruction and learning beyond the walls of the classroom. White and Martin (2014, p. 64) argue that the characteristics of mobile devices (such as capturing and collecting information, communicating and collaborating with others, consuming and critiquing media, constructing and creating personal forms of representation and expression) can be readily mapped onto mathematical, scientific, and engineering practices highlighted in the Common Core Math and Next Generation Standards (NGSS Lead States 2013).

Research on the possible uses and potentialities of mobile technologies is growing, but in mathematics education, research on this topic is still limited. Nevertheless, we can find research reports (see for example Crompton and Traxler 2015; Meletiou-Mavrotheris et al. 2015; and the special issue on mobile technologies published on the Mathematics Education Research Journal, Larkin and Calder 2015) addressing how this kind of technology could be used in the teaching and learning of mathematics.

We review some of these reports regarding the use of these technologies in mathematics education with the intention of providing an overview of the type of studies and applications that currently exist.

Before reviewing the literature, however, we briefly address two key concepts: mobile technologies and mobile learning. 


\subsubsection{Mobile technologies and mobile learning}

We first clarify what is meant by mobile devices (or technologies) and mobile learning in the literature. Authors such as Aguilar and Puga (2015) broadly define the concept of a mobile device as

... any personal and portable computer device that could be used in the mathematics classroom. This includes devices such as calculators, laptops, smartphones and tablets. (p. 178)

Most authors, however, do not seem to consider calculators and laptops as mobile devices. Although not all authors explicitly define what the term "mobile devices" means to them, it becomes evident from their studies that usually only the newest portable technologies such as smartphones and tablets are considered as mobile devices (see for instance Roberts and Vänskä 2011; White and Martin 2014).

Regarding the concept of mobile learning, one of the explicit definitions found in the literature is the following:

...learning across multiple contexts, through social and content interactions, using personal electronic devices. (Crompton 2013, p. 4)

From this perspective, mobile learning not only involves the use of portable devices, but also the ability to learn in different contexts (beyond the classroom, for example) through intertwined interactions with people, content, and devices.

\subsubsection{What kinds of studies are being developed in this emergent area?}

Early studies of mobile learning in mathematics date from shortly before 2010 (see Franklin and Peng 2008 as example), and since then we have witnessed a growth in this type of research, both at international conferences and in specialized journals. Most of the literature reviewed for this survey can be divided into three broad categories: (a) studies on the potential of mobile devices for teaching and learning mathematics; (b) affective studies on the use of mobile devices; and (c) use of mobile devices in mathematics teacher education.

(a) Studies on the potential of mobile devices for teaching and learning mathematics

Several studies have focused on exploiting the capabilities of mobile technologies, such as portability, mobility, and the capacity to take photos and videos of real phenomena that later can be analyzed and discussed from a mathematical point of view. An example is the work of
Wijers et al. (2010), who used a location-based game called MobileMath for mobile phones with GPS to allow students to create and explore quadrilaterals and their properties on a real playing field outside the classroom. The researchers found that certain features of this game (like the fact that the game in itself as a whole is competitive) result in quite an engaging experience for the students; in addition, the game allows students to notice geometrical aspects of the real world. However, the authors are cautious and warn that the collected evidence does not allow them to assure that the game has an effect on students' learning. Another example is the study of Daher and Baya'a (2012) in which mathematical applications for mobile phones are used in combination with videos and photos to allow students to perform mathematical analyses of natural phenomena that may occur outside the classroom: for example, measuring the height of lighted candle in intervals of time, registering the results, assigning points in the coordinate system, and using an app for mobile phones (called Fit2Go) to fit a linear or a quadratic function to the assigned points. The authors of this research claim that mobile phones provide students with rich and diverse learning modes (learning through formal manipulations, learning through classroom discussion, learning in an authentic environment), where learning takes place inside and outside the classroom.

\section{(b) Affective studies on the use of mobile devices}

Some studies have focused on studying the perceptions and emotions that mathematics teachers and students experience when they teach or study mathematics by using mobile devices. For example, Holubz (2015) studied the perceptions of students and teachers about an initiative called "Bring Your Own Device" (BYOD), where the use of the internet and mobile devices for the study of mathematics is promoted. She investigates how essential the participants of the initiative consider a mobile device to be in the learning of mathematics. In another study, Daher (2011) focuses on examining middle school students' emotions during indoor and outdoor activities while using their mobile phones to learn mathematics. The outdoor activities involved exploring the mathematics of real life phenomena, such as finding the relationship between the circumference of the trunk of a tree and the circumference of its biggest branch. Indoor activities in the classroom included the students discussing graphic and algebraic aspects of the phenomena that they observed and registered outside the classroom. The author of this research concludes that this type of activity promotes positive emotions in students towards the study of mathematics, such as enjoyment, comfort, pleasure, enthusiasm, interest, feeling of time passing, and curiosity; however, admittedly, some students involved in the study experienced the opposite of these emotions. 
(c) Use of mobile devices in mathematics teacher education

Finally, we note that a few studies analyse the use of mobile devices in mathematics teacher education. Yerushalmy and Botzer (2011), for instance, discuss theoretical considerations as well as challenges and opportunities underlying the design of inquiry tasks in mobile settings for pre-service and in-service teachers, as well as those related to the teaching of the construction of mathematical models in algebra and calculus. In turn, Palmer (2014) considers how the iPad, along with the use of video, can function as a tool that promotes reflection and discussion among pre-service mathematics teachers about their own learning and teaching practices.

\subsubsection{An example-mobile learning}

An example that illustrates how mobile devices can be used to promote the learning of mathematical concepts may be the work of Helen Crompton (2015). In her study, Crompton proposes a design-based research study in which iPads are used as a means to support elementary students in their learning of the concept of angle.

Based on empirical studies, she argues that the teaching and learning of angle and angle measurement can be promoted by using real-world connections. Thus, Crompton (2015) proposes to introduce students to context-aware ubiquitous learning (context-aware u-learning) in order to improve their understanding of the concept of angle. A context-aware u-learning experience is defined as "a situation in which the student is interacting with a real-world environment while using a mobile technology to support his or her learning" (p. 20).

In this learning context, the students used their mobile devices to identify and photograph angle- like shapes that naturally appeared in their surroundings (for example in a tree stump, in a shoe pattern, or in the corner of a table); the students then analyzed these images using dynamic geometry applications contained in their mobile devices. In particular, students overlapped the captured images with drawings of real angles using the geometric software. In this way the students analyzed whether the "natural angles" that they found in their physical environment actually conformed to the mathematical properties of an angle.

When assessing the effects of her instructional design, Crompton reports an improvement in most students' understanding of the concept of angle, She reports that, after experiencing the educational intervention, most began to analyze triangles, paying more attention to their mathematical properties rather than to their visual appearance.

This is an example of how mobile devices can serve as a bridge to connect physical experiences and real-world objects with the mathematics studied in the classroom. As the researcher claims, "the use of the application on the iPads was providing a way for students to mathematize the real world. Instead of students looking through a text book to find individual instances of angles in traditional formats, the students were using the technology to see that there were angles in multiple forms even in one photograph taken with the application" (p. 24).

We believe that the use of mobile devices in the teaching and learning of mathematics is an emerging research area, but also one that is expanding and growing quickly. Surely in the years to come this area will glean more interest and followers among mathematics educators from all over the world. However, we must be cautious: even though mobile devices and their characteristics appear to offer vast opportunities to enrich and transform the practice of mathematics education at all levels, the introduction of these devices in the classroom also pose a number of challenges of a different nature (pedagogical, technical, and management related, as noted in the preface written by Meletiou-Mavrotheris et al. 2015). We need to consider and study this idea in order to achieve a beneficial and productive integration in the mathematics classrooms.

\subsection{MOOCS in mathematics education}

Massive Open Online Courses (MOOCs) offer opportunities as well as challenges for distributing knowledge from institutions. Mathematics and mathematics education are not exempt from these new initiatives (Committee on Electronic Information and Communication 2014; Gadanidis 2013; McCulloch and Rothschild 2014). Some descriptors used to characterize MOOCs are course, open, massive, participatory, distributed, and life-long networked learning. In the mathematics education context, MOOCs are "courses" because there are learning objectives, content and resources, facilitators, ways to connect and collaborate, and a beginning and an end to the learning experience. MOOCs typically use a multimedia format and resources are often short videos on specific topics. They are "massive" since there is not a limit to the number of people who can participate. They are "open", since typically no prerequisites exist for taking a MOOC. MOOCs can highlight some of these features, but others do not, and they even use different acronyms to reflect another emphasis (xMOOCs or MOOR when the focus is on resources and cMOOCs when the focus is on connectivity). Furthermore, most MOOCs offer an optional evaluation process. Participants who complete the evaluation process have the option of receiving a certificate of completion, which typically requires a course fee.

MOOCs are built on the assumption of pervasive internet access. While internet access is not yet as widespread in 
developing countries as one might think, the rapid increase in the ease of access to technology suggests that it will be possible in a few years (Borba et al. 2013). This emerging access, coupled with the lack of prerequisites for enrollment, allows MOOCs to reach a large numbers of participants. Since MOOCs allow participants to complete as much or as little of the course as they desire, MOOCs offer self-directed learning opportunities. These types of courses deliver resources and supplemental materials on specific topics while allowing participants to follow their own paths consistent with their needs. In mathematics education, the introduction in USA of Common Core State Standards (CCSS) has promoted the emergence of MOOCs to facilitate CCSS dissemination and training. For example, the MOOCs for Educators (MOOC-Ed at Friday Institute, NC State, College Education) Mathematics Learning Trajectories for the Common Core is a professional development series focusing on learning trajectories as a framework for interpreting and implementing the Common Core State Standards in Mathematics (CCSS-M) (see https://place. fi.ncsu.edu/mod/page/view.php?id=386). The goal of these online professional development courses is that participants develop a foundation for understanding and promoting student conceptual growth as they implement the new standards. On the other hand, Boaler (2014), using a Stanford's online platform, provides a MOOC to help prepare teachers and students for new common Core State Standards (CCSS), and also offers it to administrators and parents and as a free online course which is also available in Spanish. The course consists of short videos and thinking tasks to promote active engagement and provide practical methods that can be immediately used in classrooms combined with research on high quality mathematics teaching. This course has no formal evaluation and is designed for anyone who wants to improve his or her relationship with mathematics (Boaler 2014).

In some cases MOOCs facilitate a collaborative professional experience through a virtual social space for discussion, sharing ideas, resources, and opportunities for constructive feedback. These MOOCs provide open access to resources and social space to develop the individual dimension of learning. Participants in these MOOCs are engaging in the learning process with others. The learning with others is an important factor in most MOOCs, which offer participants a way to connect and collaborate in networked and connected learning environments. Such collaborative learning (and even assessment) is necessary in large MOOCs, where student- instructor ratio is very high. When connectivity is valued in the design of a MOOC (cMOOC) the course allows for shared knowledge and practices that harness the power of social and participatory media to enable participants to communicate and collaborate through a variety of channels. In these cases, MOOCs promote peer coaching and collaboration. Additionally, there is not just a single path in which the network of participants and ideas is developed; engagement can use different modes (e.g. blogs, Twitter, virtual forum) to build a distributed knowledge base. For example, the MOOCs designed by The Open University in India, in which freely available learning materials and educational resources can be adapted in particular contexts, create a social space to support interaction between colleagues to share previous experience and knowledge for primary and secondary teachers of mathematics, literacy, English and science (The Open University 2015). Such connectivity is also presented when the goal of the MOOC is to build peer learning communities, sharing epistemologies of practice for the purpose of professional development, such as in mathematics and science teacher development in native American Pueblo schools (Kilde and Gonzales 2015). Sharing a new approach to mathematics teaching from new standards or curriculum creates the context for teachers' learning from a connectivity learning perspective.

\subsubsection{MOOCs in massive professional development initiatives: the case of Costa Rica}

In the context of curricula development initiatives when new mathematics curricular standards or principles are generated, teachers are considered to be change agents (Llinares et al. 2014). A MOOC may be used to meet the challenge of implementing new curricular standards. We present one example of massive professional development initiatives from Costa Rica using an adaptation of the MOOC concept. The features of the MOOC as a course, and as being open, participatory, distributed, and a life-long networked learning environment, have been adapted for a specific context in Costa Rica, revealing the contextualized nature of MOOCs.

The goal of the adaptation of MOOCs in this initiative in Costa Rica is to support in-service teachers in the gradual implementation of the new curriculum (Ruiz 2013). The project provides various types of professional development initiatives for teachers, ranging from face-to-face, to virtual, to blended-a mix of face-to-face and virtual approaches. These courses are designed to be "massive" in that they will prepare school leaders to replicate the content of MOOCs in their regions of country. However, in this first version of the course, participant quotas are established in order to facilitate studying the MOOCs impact on the teaching practice. The courses use the platform Moodle and afford participants opportunities to follow their own learning paths and their own schedules. The courses present key ideas that organize the new curriculum through examples of strategies to interpret and implement them. The sessions include various thinking tasks through the analysis of 


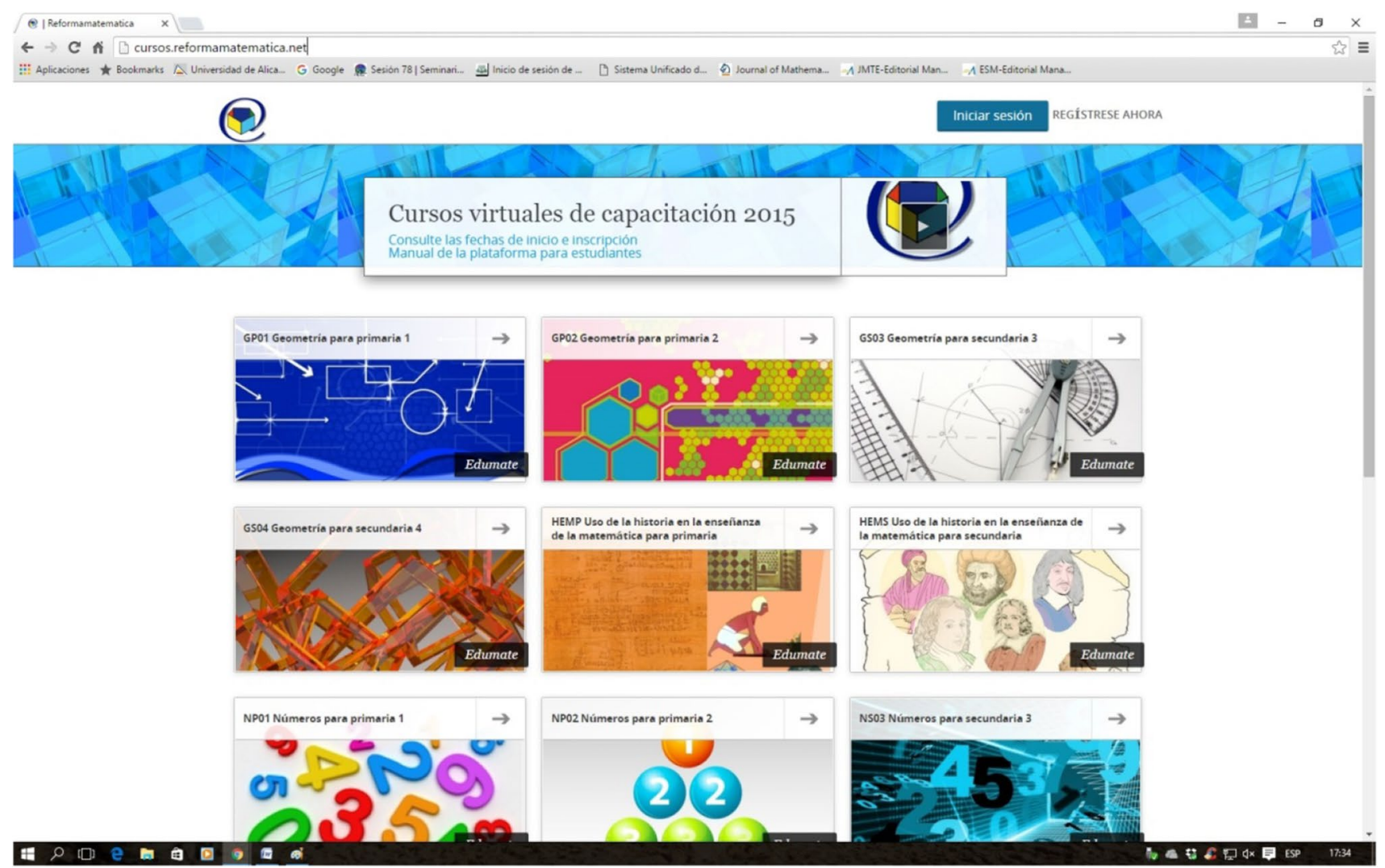

Fig. 1 Presentation of courses from Reforma de la Educación Matemática en Costa Rica (http://www.reformamatematica.net)

high quality mathematical tasks (Fig. 1) that can be solved in many ways and represented visually, emphasizing conceptual thinking. Furthermore, video and other multimedia are used to present the mathematical content framed within pedagogical strategies as part of blended courses (bimodal courses). Integration of slides and video-clips enable presenting a course's content in a dynamic way, emphasizing the key idea in the new curriculum of "problem solving with special emphasis on real contexts". The modular teaching mini-videos (Unidad Virtual de AprendizajeUVA) as a complement of the design of these courses enables presenting the use of technology in mathematics teaching through the solving of real problems.

One characteristic of this use of MOOCs is that participants also have some face-to-face support through meetings in several educational regions. The face-to face meetings, together with guided video support, help orient participants at all times about what to do, and how to decide what materials or links they need to access. The use of a technical forum about platform issues and an educational forum about content complement the face-to-face meetings. Although the participants have freedom to guide their own learning pace, there is a timetable in order to organize activities, and participate in debates (blogs, forums, etc.). A network of participants can be created through participants' posts in the social virtual space, as they discuss key ideas about the new curriculum and its implementation. These methods of interaction provide a basis for generating virtual communities and networks of mathematics teachers, allowing for the building and sharing of new ways of thinking about the teaching of mathematics. In this sense, a primary goal of creating these learning environments using an adaptive MOOC is to generate communities of practices (CoPs) among in-service teachers. The in-service mathematics teachers in these MOOCs do not receive official credits for professional promotion, rather only a certificate of participation (in this case, the certification is digital and personal from a web-page). So these MOOCs are for teachers interested in learning more about mathematics teaching based on the new curriculum and interested in making connections with others to share ideas about teaching-learning mathematics.

\subsection{Digital library and designing learning objects in mathematics education}

As stated in the Digital Library Manifesto (Candela et al. 2007), digital library is potentially a virtual organization, which comprehensively collects, manages, and preserves rich digital content of all forms for its users. Obviously, 
digital libraries need a digital repository. In the context of education, digital repositories use learning objects to organize their content, which is a different method of organizing learning content than printed materials use.

Learning objects (LO) proposed by IEEE (2002) are elements of a new type of e-learning grounded in the objectoriented approach of computer science. LO can be defined as a digital entity that can be used, reused, and tagged with metadata aimed to support learning. Therefore the difference between a learning object and a digital content is that, besides its object-oriented features, a learning object includes a pedagogical aspect.

Accessibility, interoperability, and reusability are the main features of a learning object (Polsani 2003). Accessibility refers to the tagging of learning objects with metadata. Interoperability refers to the method of sharing learning objects with other technology systems without the need to alter these objects. We suggest that two standards provide interoperability: metadata and content packaging standards. Reusability refers to the use of learning object in multiple learning environments. The idea of creating learning content and making them accessible, reusable, and interoperable introduces a new kind of challenge for instructional designers.

Designing LOs is a four-step process: developing content, packaging, distributing, and storing it in a repository, a so-called digital library. The challenge of designing learning objects occurs when a user wants to use more than one learning object together in an integrated way. Another consideration is the size of the learning object, which remains an additional problem instructional designers need to tackle (Altun and Askar 2008). One of the studies was actualized by Baki and Çakıroğlu (2010) in a high school mathematics classroom by using a modified ADDIE model. The researchers developed learning objects and prepared a Learning Object Repository (learning objects are stored in databases called learning object repositories). The study was conducted in a real setting and reviews of students and teachers were observed. The results showed that the use of LOs can be effective in high school mathematics classrooms.

Atkins (2007) used "digital objects" or "digital learning objects" as the building block of the Open Educational Resources (OER) available in Learning Object Repositories (LORs). In their report, they defined OER as teaching, learning, and researching resources that reside in the public domain or have been released under an intellectual property license, which permits their free use or re-purposing by others. Open educational resources include full courses, course materials, modules, textbooks, streaming videos, tests, software, and any other tools, materials, or techniques used to support access to knowledge. There is a rapidly growing number of OER in LORs. Well-known learning resources in online repositories are MERLOT (Multimedia Educational Resources for Learning and Online Teaching), Wisc-Online, DRI, Khan Academy, and EBA (Digital Repository of Turkey).

\subsubsection{The multimedia educational resource for learning and online teaching}

The Multimedia Educational Resource for Learning and Online Teaching (MERLOT) was founded in 1997. A program of the California State University, it has been widely used internationally. MERLOT is free to use and is sustained through the support of higher education institutions from around the world. In MERLOT, resources are categorized in 14 different types of materials (Simulation, Animation, Tutorial, Drill and Practice, Quiz/Test, Lecture/ Presentation, Case Study, Collection, Reference Material, Learning Object Repository, Online Course, Workshop and Training Material, 3D Object, and Open Textbook) and are organized in different collections of disciplines: Arts, Business, Education, Humanities, Mathematics and Statistics, Sciences and Technologies, and Social Sciences. Many higher education and K-12 institutions, non-profit associations, special interest groups, and corporations have adopted and integrated MERLOT services (see Fig. 2 for a screenshot) into their online education initiatives. MERLOTII was published on Oct 7, 2013 (see https://www.merlot.org/).

\subsubsection{Wisc-online}

Wisc-Online is a digital library of Web-based learning resources called learning objects. The digital library of objects has been developed primarily by faculty from the Wisconsin Technical College System and produced by software and multimedia developers who create the learning objects for the online environment. At present, over 400 of their faculty members have authored learning objects. The Wisc-Online digital library contains over 2500 learning objects that are freely accessible to teachers and students at no cost and with copyright clearance for use in any classroom or online application. Learning objects are designed and developed by a team of instructional designers, editors, technicians, and student interns. The types of learning objects are Assessments, Animations, Simulations, Case Studies, Drill and Practice, and Templates (see https:// www.wisc-online.com).

\subsubsection{The digital repository of Ireland}

The digital repository of Ireland (DRI) is a national trusted digital repository for Ireland's social and cultural data. The repository links together and preserves both historical and contemporary data held by Irish institutions, providing a 

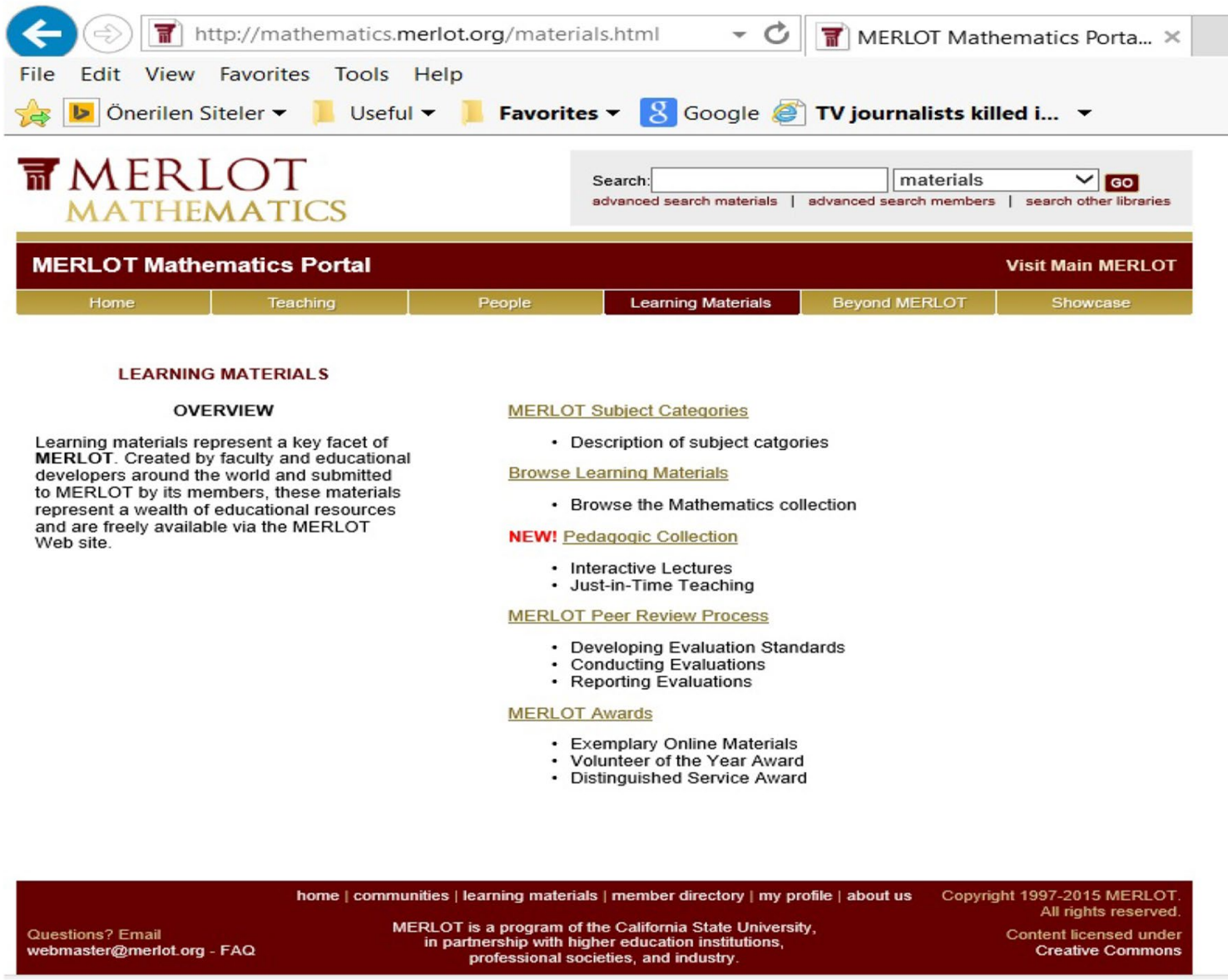

Fig. 2 A screenshot from MERLOT Mathematics Portal

central internet access point and interactive multimedia tools. As a national e-infrastructure for the future of education and research in the humanities and social sciences, DRI is available for use by the public, students and scholars (see http://dri.ie).

\subsubsection{Khan Academy}

Khan Academy (see Fig. 3 for a screenshot) is a personalized learning resource for all ages; it offers practice exercises, instructional videos, and a personalized learning dashboard enabling learners to study at their own pace in and outside of the classroom. Their mathematics missions guide learners from kindergarten to calculus using stateof-the-art, adaptive technology that identifies strengths and learning gaps (see https://www.khanacademy.org).

\subsubsection{EBA of FATIH project in Turkey}

The Ministry of National Education, Turkey, designed the Movement of Enhancing Opportunities and Improving
Technology (FATIH) project to provide interactive white boards, tablets, and Internet network infrastructure to all schools in basic education (the pre-primary and primary levels are to receive ISBs, while lower and upper secondary levels will receive interactive white boards as well as tablets). The goal of this project is to enhance equality of opportunity in education and to improve digital technology use in teaching and learning in schools. FATIH intends to set up digital technology hardware in 40,000 schools and 6,20,000 classrooms across Turkey. The project was initially launched in secondary schools but will eventually reach all grade levels between 2011 and 2019 (ERG 2013).

The Educational and Informatics Network (EBA, see Fig. 4 for a screenshot) which has been designed under the component of the FATIH project, is an educational e-content portal. EBA includes the modules: TvRadio, Visual, z-book, game, R\&D, project, e-cyclopaedia, e-lesson, e-content, lesson supportive tools, news, school information network, question and answer (see http://www.eba. gov.tr). 


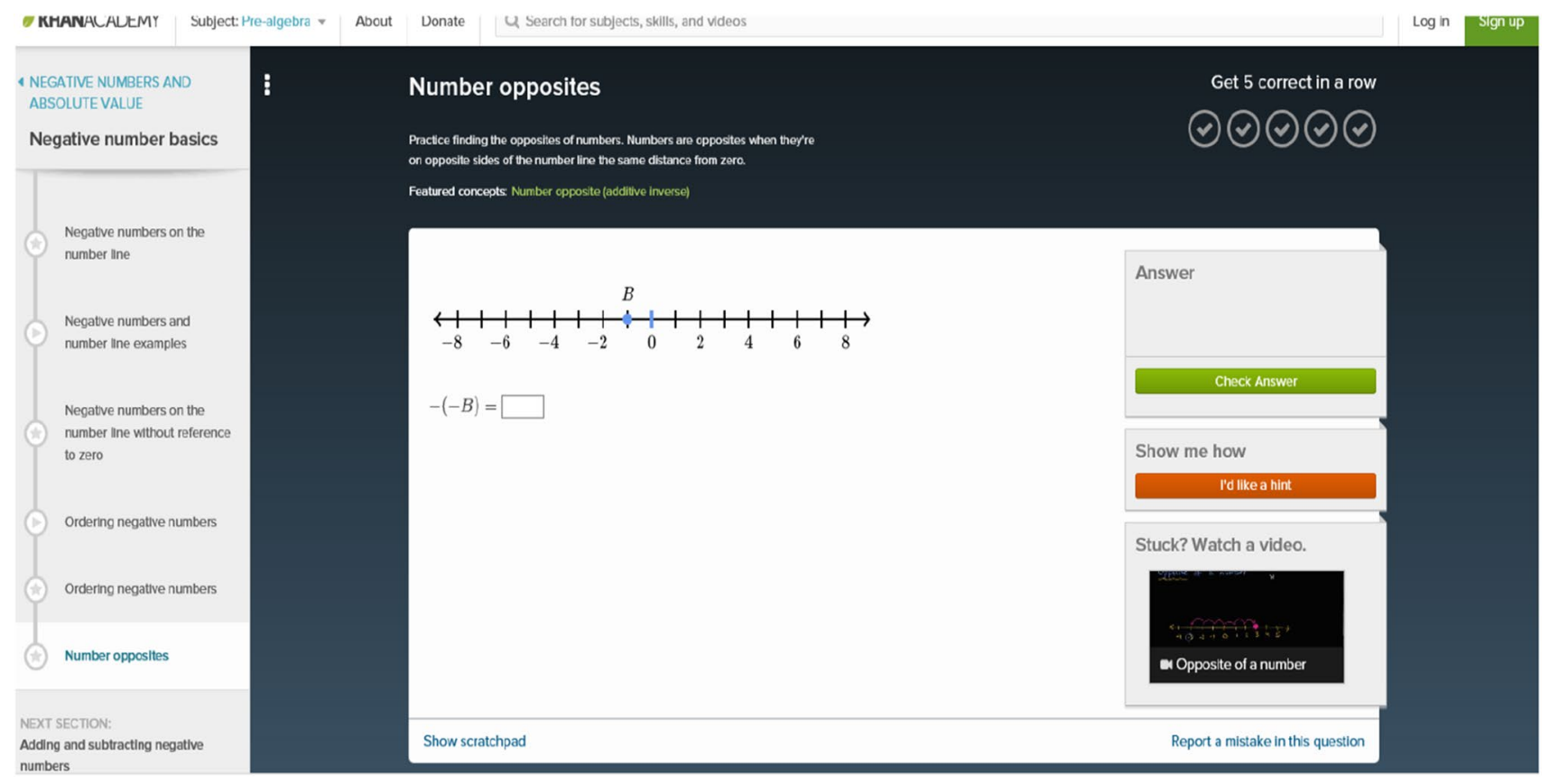

Fig. 3 A screenshot from Khan Academy portal

\subsubsection{An example for mathematics education: what will you do in math today? Western University, Canada}

What will you do in Math Today? (available at http:// researchideas.ca, see Figs. 5 and 6 for screenshots) is an online open repository of resources for mathematics education, created by Gadanidis at Western University, Faculty of Education, Canada. The portal is supported by various institutions in collaboration with Borba, Hughes, Namukasa, Kotsopoulos and Scucuglia, and includes a researchbased math text with learning objects categorized as number, pattern and algebra, measurement and geometry, data and probability. It also offers teaching and learning resources and activities math and coding. There are tools to help teachers develop their lessons and courses for mathematics. The portal is a comprehensive online environment for teachers, students, and researchers in the field of mathematics education.

Current learning object studies have been focusing on quality measures, personalization, and mobile learning. Gadanidis et al. (2004) analyzed the pedagogy and interface design of interactive visualization for mathematical investigation. They concluded that many interactive visualizations do not appear to be well designed, either from a pedagogical nor from an interface design perspective. Studies have shown that quality assurance of the LORs is a significant factor when predicting the success of repositories (Clements et al. 2015). Therefore, developers of LORs are responsible for providing quality assurance information to the users. LOR quality approaches range from metadata quality, peer review, and users' ratings to intrinsic metrics for automated quality classification tasks. Cechinel et al. (2011) have shown that intrinsic metrics vary according to discipline. For example "number of images" is positively associated with materials in the discipline of mathematics and statistics, but negatively associated with materials in the discipline of social sciences. Another major issue in the development of learning objects is personalization, that is a system adapted to the learning styles, prior knowledge, cognitive style, and achievement of the user. An additional research area focuses on adapting LORs for use with mobile devices, which play an important role in teaching and learning. Authors such as Kinshuk and Jesse (2013) highlighted the need for standardization of the learning objects in terms of software design for mobile applications.

Students today often turn to online mathematics learning resources, such as digital libraries and learning objects before consulting a teacher or a textbook. As mathematics educators, we need to develop and organize these resources in such a way that they facilitate access and foster conceptual understanding.

\subsection{Using technology in collaborative learning}

Opinions have been aired that technology enhanced learning has not succeeded in revolutionizing education and the learning process (Chatti et al. 2010a). One reason suggested is that most current initiatives take a technologypush approach in which learning content is pushed onto a pre-defined group of learners in a closed environment Some 
Görsel Matematik / 101 adet

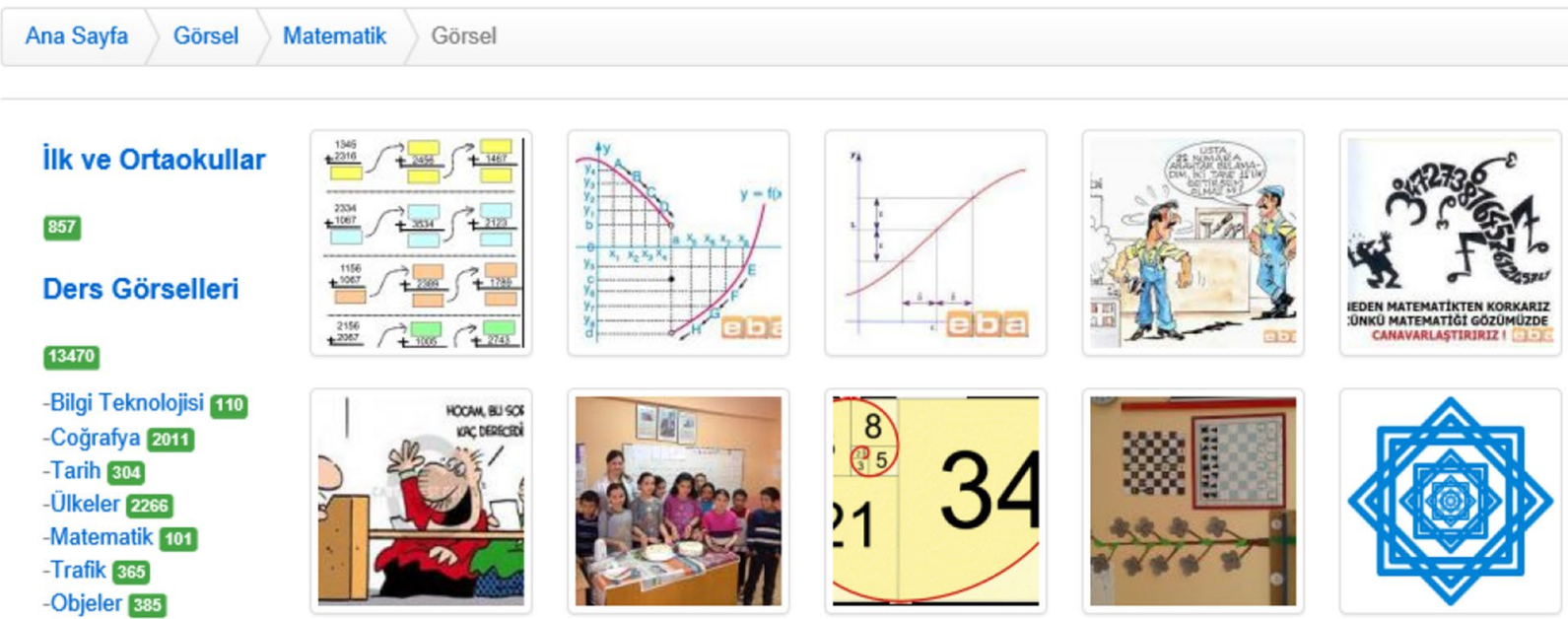

Fig. 4 A screenshot from EBA portal showing mathematics learning objects

feel a fundamental shift toward a more open and studentpull model for learning is needed - a shift toward a more personalized, social, open, dynamic, and knowledge-pull model as opposed to the one-size-fits-all, centralized, static, top-down, and knowledge-push models of traditional learning. Chatti et al. (2010b) suggest a learning model (which they call the 3P model) as a new approach for addressing the growing complexity and constant change in knowledge that is tailored to and required for the new generation. This model encompasses three core elements: personalization, participation, and knowledge-pull.

Roger and Johnson (1988) surmise that how students perceive and interact with one another is a neglected aspect of instruction. Although much training time is devoted to helping teachers arrange appropriate interactions between students and materials and some time is spent on how teachers should interact with students, too little time is spent on how students should interact with one another. Since learning is situated in practice and all practice is essentially social in nature (Swan and Shea 2005), much learning takes place in networks. A more social and connected Web has arisen over the past years, which strongly supports the idea of network learning. Students prefer on-demand access to all kinds of knowledge disseminated over the internet, and absorb knowledge rapidly across different channels. They are in close contact with their friends, using networks to share and create new knowledge. This new Web generation is often termed Web 2.0 (Chatti et al. 2010a).
The concept of an open network learning environment is discussed by Tu et al. (2012).

Open network learning environments are digital environments that empower learners to participate in creative endeavours, conduct social networking, organise/ reorganise social contents, and manage social acts by connecting people, resources, and tools by integrating Web 2.0 tools to design environments that are totally transparent, or open to public view; the same architecture can be used to design the degree of openness users feel is necessary to the situation. (p. 14)

The authors detail an online course designed to empower learners to construct their own personal learning environments within open network learning environments. They conclude that effective instructions should prepare "online" learners to become "network" or "open network" learners.

\subsubsection{Communities of practice (CoP)}

$\mathrm{CoP}$ are sometimes seen not as domain-specific communities, but rather as linked, dispersed, and extended communities collaborating on common tasks (Buchem et al. 2011). CoP were inspired by Lave and Wenger (1991) and have been adapted in several contexts in mathematics teacher education (Llinares and Olivero 2008) and different mathematics courses (Borba and Gadanidis 2008). Learning takes place through bringing together knowledge with practice, 


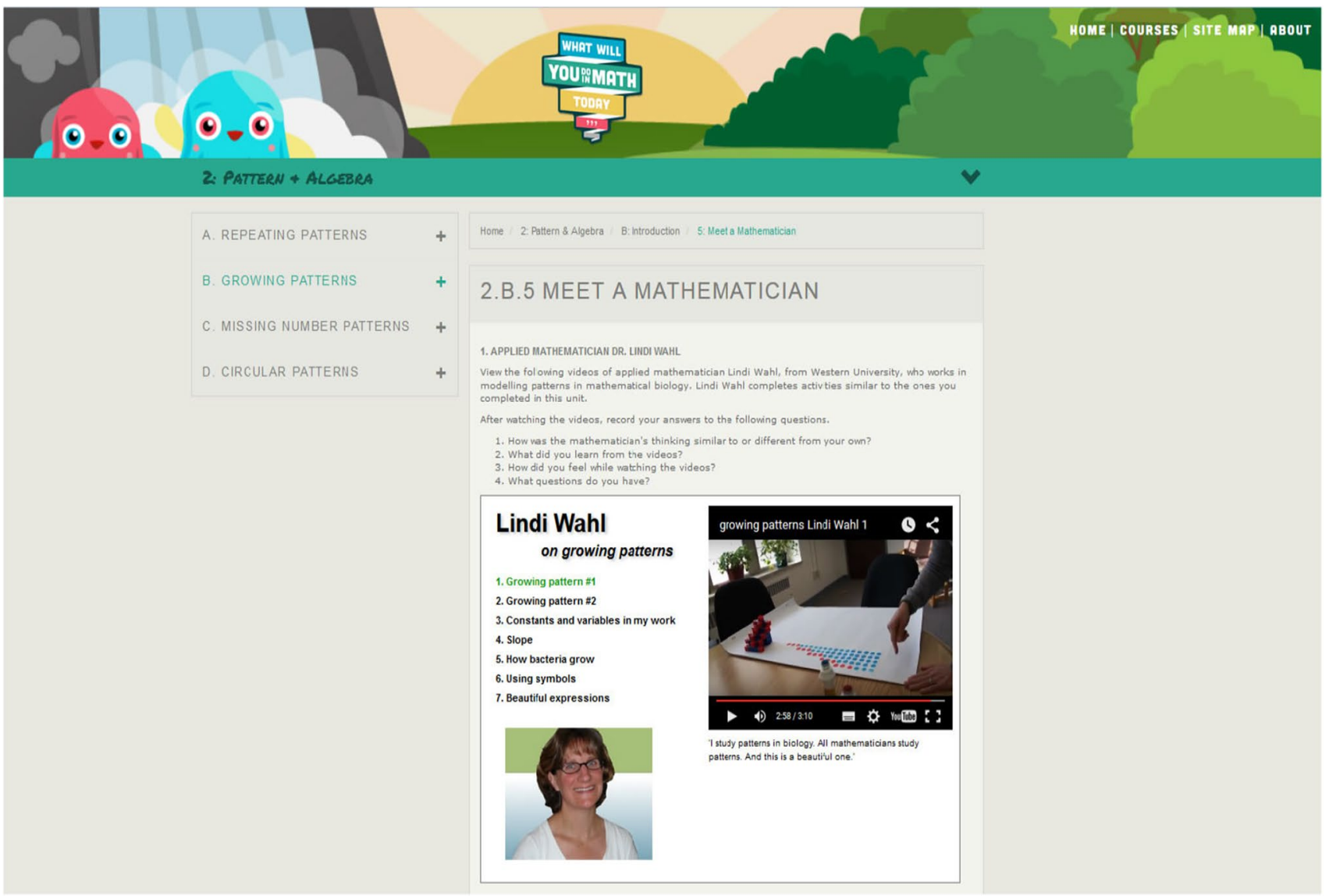

Fig. 5 A screenshot from What will you do in Math Today? showing an interview with a mathematician doing the same activities as very young students

facilitated by social applications such as blogs or wikis. Through inquiry and collaboration, engagement in such communities provides support and motivation for learning.

\subsubsection{Virtual learning environments (VLE)/learning management systems (LMS)}

A VLE or LMS is a Web-based platform for courses of study, usually within educational institutions. LMSs (or VLEs) could allow participants to be organized into groups; present resources, activities and interactions within a course structure; provide for the different stages of assessment; report on participation; and have some level of integration with other institutional systems.

LMSs have been adopted by universities all over world at a remarkable rate (Coates et al. 2005). A case can certainly be made for enhanced learning resulting from appropriate utilization of the features of an LMS.

However, incompetent use of LMSs (especially the posting of static content on an LMS) has been criticized. Chatti et al. (2010a) bluntly state that the LMS-centric model of learning has failed to improve performance. In most cases an initially paper-based learning resource is simply converted into digital format, and a classroom training event is transformed into an online course. The pattern is of modularization of courses and isolation into discrete units. Consequently, LMS-driven models suffer from an inability to satisfy the heterogeneous needs of many learners.

García-Peñalvo et al. (2011) argue that with LMSs users have reached a plateau of productivity and stability, and that this stability of the LMS may become a resistance factor working against the introduction of innovations.

\subsubsection{Personal learning environments (PLE)}

The idea of PLEs was preceded by VLEs. Although the first mention of a PLE was heralded much earlier (Buchem et al. 2011), the concept of PLEs became well-known in the beginning of this century through the work of Attwell (2007), Chattiet al. (2010a), Drexler (2010), Johnson and Liber (2008), Wilson (2008), and Wild et al. (2010). The first recorded mention of PLE as a concept is found in a paper by Olivier and Liber (2001). 


\section{CAN WE MAKE THE GRAPH CURVE?}

One type of curve is called a parabola:

- Satellite dishes are parabolic in shape.

- So are the mirrors used in headlights and flashlights.

- A ball thrown travels a parabolic path.

- Move the sliders below to explore parabola equations and graphs.

-What do you notice?
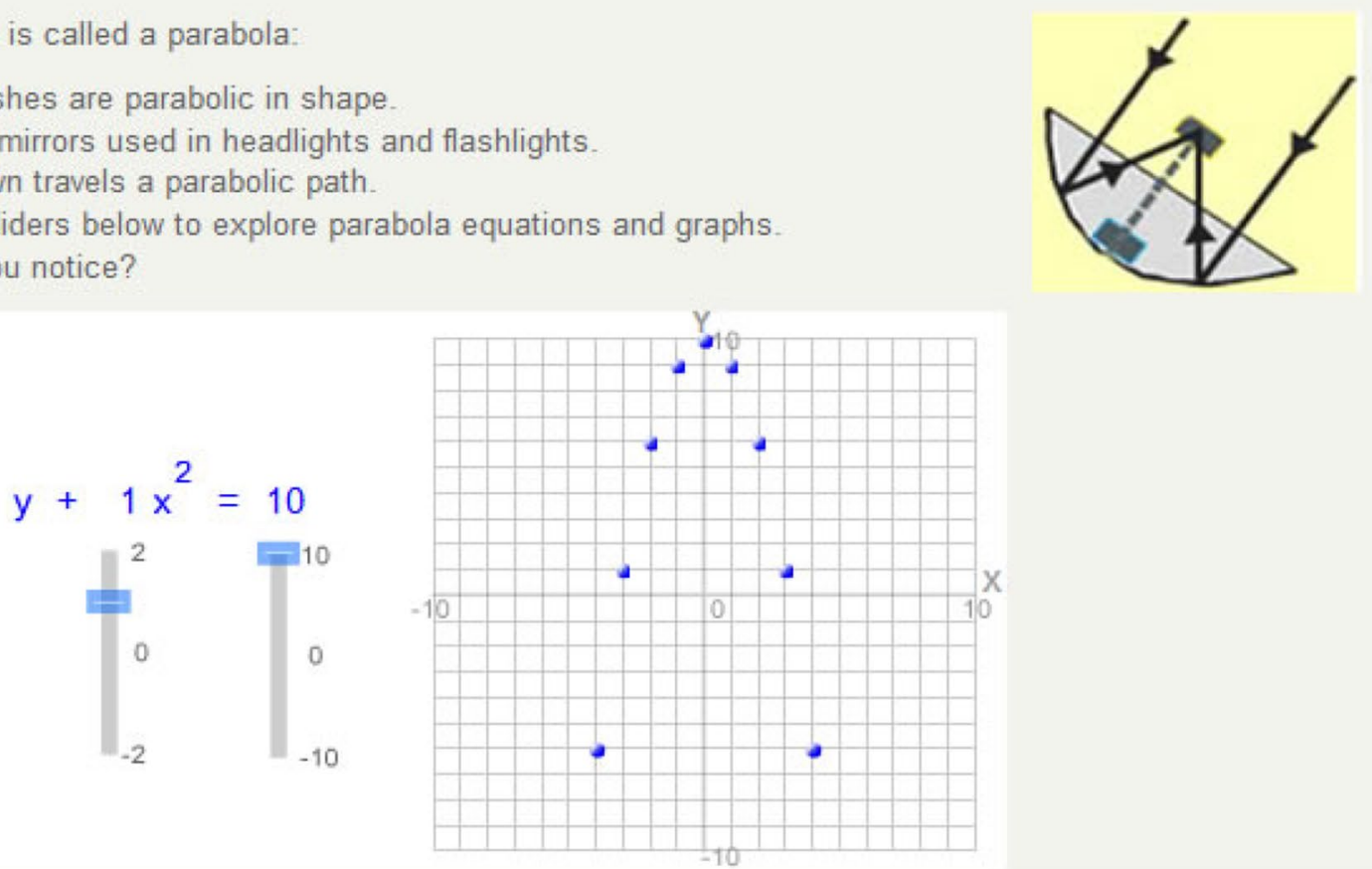

Fig. 6 An example of a learning object from Research Ideas

Buchem et al. (2011) led a comprehensive review of the literature (over 100 publications) on PLEs in 2011. They see a PLE as a "concept related to the use of technology for learning focusing on the appropriation of tools and resources by the learner" (p. 1). Martindale and Dowdy (2010) describe a PLE as a "manifestation of a learner's informal learning processes via the Web" (p. 182). PLEs are systems that provide support to students so they can take control of their learning (by setting their own learning objectives) and manage their own learning content to achieve these learning objectives.

A PLE may consist of a number of subsystems, such as a desktop application and one or more web-based services. A PLE could integrate formal and informal learning, such as using social networks, and could use collaboration possibilities, such as small groups or web services, to connect a range of resources and systems in an individual space.

PLE's can be viewed as the latest step in an alternative approach to e-learning. The concept has been developed in concert with that of a LMS - the difference being that a LMS is course-wide (or institution-wide), while a PLE is individual.

A number of special issues of journals devoted to PLEs have been published, e.g. special issues in Interactive Learning Environments, Digital Education Review, and the International Journal of Virtual and Personal Learning Environments (IJVPLE).
Different research foci on PLEs include a more pedagogically-oriented research focus as illustrated by Attwell (2007) and by Drexler (2010), for example; and a more technologically-oriented research focus found in Chatti et al. (2010a, b), Milligan et al. (2006), and Wild et al. (2008).

Students do not have control over what is taught but do have control over what is learned (Tobin 2000). For this purpose students create a PLE, a collection of all tools they use for learning, thereby enabling a learner-controlled integration of myriad learning tools and services into a personalized space. The idea is to provide a student with a variety of possibilities and allow the student to select, use, and mashup the services in any way he/she deems fit (Chatti et al. 2010a).

Ivanova (2009) found the main challenges in forming PLEs are to provide sustainable value to students and stimulate students to contribute their knowledge, insights, and experiences on a continuous basis. She found that social networks contribute to the processes through learners meeting and sharing their competencies.

Conde et al. (2011) suggest that LMSs should be integrated into PLEs, thus integrating informal learning tools and contexts with formal environments. Derek Morisson in Sclater (2008) also advises on how PLEs can "dock into the LMS" every so often, to bring or acquire content.

There are a number of electronic social networking platforms for PLEs; accordingly we mention Elgg and SMC. 
Elgg was developed in 2004 by Werdmuller and Tosh (see https://elgg.org) bringing ideas found in commercial social networking platforms to education. Elgg is a social networking engine, providing the building blocks that enable educational institutions to create their own social networks and applications. It offers blogging, micro blogging, file sharing, networking groups, and a number of other features. Sarasty and Fernández (2015) experimented with Elgg at the University of Cauca in Colombia to test the technology platform in supporting learning processes in mathematics. They conducted two case studies in which they developed various activities for students and teachers. The activities were designed to obtain data about the students' prior knowledge of ICT and their use and acceptance of services on the platform, as well as the impact of these activities on their learning.

The social media classroom (SMC) was developed by Rheingold (see http://socialmediaclassroom.com). It includes a free and open-source web service that provides teachers and learners with an integrated set of social media. The platform includes tools such as an integrated forum, blog, comment, wiki, chat, social bookmarking, widgets and video commenting. SMC also includes curricular material such as syllabi, lesson plans, resource repositories, screencasts and videos.

\subsubsection{Personal learning networks}

Related to the concept of a PLE and sometimes indistinguishable from them, is the idea of a personal learning network (PLN). Whereas PLEs are the tools, artifacts, processes, and physical connections that allow learners to control and manage their learning, PLNs extend this framework to include an informal learning network of people to connect with for the specific purpose of learning. In a PLN there is an understanding among participants that the reason they are connecting is for the express purpose of active learning. (Lalonde 2012). So, a PLN is based on reciprocity and a level of trust, understanding/assuming that each party is actively seeking value-added information for the other (Tobin 2000).

PLNs are closely linked to the idea of CoP. By providing authentic social interactions, PLNs contribute to the collaborative development of educational resources and the shared development of learning networks (Buchem et al. 2011).

In such a personalized learning environment, the student chooses which PLEs, LMSs s/he wants to participate in, chooses whom to interact with in these media, and chooses how much to participate. Students enter the PLE with specific goals, needs, interests, and motivations that are often presented to others within their PLN. The student collaborates and connects differently with various members of the
PLN, establishing stronger relationships with some members and a lower level of connection with others.

The European Union Lifelong Learning Programme 2007-2013 has recognized the potential for PLNs by funding the aPLaNet project (Autonomous Personal Learning Networks for Language Teachers).

\subsubsection{Mashups}

In the early 21 st century, the creation of rich learning mashups (mostly web applications that integrate complementary elements from different sources) currently associated with collaborative learning, resulted from advances in digital media. Wild et al. (2010) describe mashups as "the frankensteining of software artefacts and data" (p. 3). They describe the development of a technological framework enabling students to build up their own personal learning environments by composing web-based tools into a singleuser experience, getting involved in collaborative activities, sharing their designs with peers, and adapting their designs to reflect their experience of the learning process.

\subsubsection{Mupples}

Wild et al. (2008) introduced the term mupple (mash-up personal learning environment). Mupples typically consist of distributed web-applications and services that support individual and collaborative learning activities in both formal and informal settings. These PLEs would complement an LMS with additional services and with external learning tools. Technologically, a mupple manifests in a learning web where information is distributed across websites, and activities can easily encompass the use of a number of services offered through web-based learning applications (Wild et al. 2010).

\subsubsection{PLEs and PLNs in mathematics education: a case study}

PLEs and PLNs have been extensively implemented in teaching computer science students in particular. In mathematics education these approaches have not really been researched sufficiently. Harding and Engelbrecht (2015) introduced the term personal learning network clusters as small groups of people who regularly interact academically and whose PLNs have a non-empty intersection that includes all the other members. Where a student's PLN could consist of a number of other students not all doing the same subjects, a PLN cluster would be a subset of the student's PLN, a smaller group of students that are together to address a particular subject or topic. They investigated PLN clusters that spontaneously formed among students in two fields of study-mathematics and computer science. 
Students in a cluster use a number of tools to communicate and learn while using social media, mobile phone technology and LMSs, among other platforms for learning purposes.

The researchers report positively about how important these groups are in the academic lives of students. Through their participation in the clusters, students take ownership of their learning and are vocal in describing the benefits that these clusters offer.

A comparison between the mathematics and computer science students reveals some commonalities and some differences. Computer science students have richer mashups of activities, and although leaning more towards digital communication, the limited amount of face-to-face communication among these students came as a surprise. Mathematics clusters are more prone to face-to-face communication. Yet both sets of clusters have the academic interest of the members at heart, and cluster activities centre around this aspect.

Students in this study are of the opinion that although collaborative learning has been in existence for a long time, with the help of current technological advances, it has gained momentum through PLN clusters. Ongoing communication is possible, and it is notable that the almost continually available helpline is one of the most valued features. The role of the lecturer with respect to PLN clusters is becoming uncertain and his/her supporting function seems to be diminishing, an aspect that should be viewed positively.

Spontaneous formation of knowledge-pull communities results in the formation of PLN clusters separate from the formal academic program. Life-long learning is the order of the day, and the longevity of the PLN clusters is testimony to blurring the boundaries of courses and semesters.

This "case study" shows that students spontaneously use modern technology to embark on collaborative learning. The tension between individual independence and collective cooperation has been debated in literature (Wagner 1995). Paulsen (2003) claims that online education can foster not only freedom for the individual but group cooperation as well, an idea he terms collective freedom. The fact that participation in a PLN is voluntary (it is initiated by the students themselves and not a forced activity) may contribute to a measure of collective freedom for students.

Too little has been done with using the concepts of PLEs and PLNs in the teaching of mathematics - a conceptual subject in which we know that collaboration increases the chances of students developing an understanding of the concepts. In fact, different from the other development trends that were discussed, we could not really find a strong case study involving mathematics education.

On the other hand, there are reports, (Borba et al. 2014) of using social networks, such as Facebook, in teaching online courses and in "blended-face-to-face courses."
Although we do not yet see the use of Facebook as a trend that justifies it being classified as one of the themes here, we believe that Facebook has distinct characteristics that could eventually position it either in this theme or in the next one regarding blended courses. In online courses, closed groups in Facebook were found to develop the same facilities of platforms as in a previously discussed VLE, but they had the advantage, as these authors say, that "students are on Facebook" (p. 86). There was no resistance to going to a PLE, because most teachers in the continuing education course the authors studied "were already in Facebook." Another example in an undergraduate mathematics course, found Facebook was used to facilitate communication with students who rarely seem to look at e-mail anymore. It was used also as help desk. Authors reported that on Saturday afternoon one student posted to this Facebook group (involving all students of class, the professor, and a teacher assistant) that she could not solve a given problem. A teaching assistant was online and responded using GeoGebra, a word editor, and a screen recorder program. The student was so happy with the feedback, that she invited other students to see the solution and study with her.

\subsection{Math-for-teachers as a blended course: an elementary teacher education case from Canada}

Blended learning, which combines both online and face-toface classroom experiences, is becoming common practice in education at all levels (LaFee 2013; Owen and Dunham 2015). The online experience can offer students opportunities to revisit and extend ideas and concepts they had previously encountered in the face-to-face classroom. It can also be used as a way to "flip" the classroom experience by giving students opportunities to encounter, explore, and reflect on ideas and concepts before they engage with them in the face-to-face classroom. Studies show that the online component of blended learning increases student agency (allowing them to control both instructional pacing and sequence), reduces distractions that are typical in classrooms or lecture halls, increases time-on-task, and improves student performance (Allen and Seaman 2010; Chen et al. 2010; Du 2011; Fulton 2012; Keller et al. 2009; Owen and Dunham 2015; Smith and Suzuki 2015; Smith and Smith 2012; Tabbers and Koeijer 2010). The flipped classroom model also allows instructors more face-to-face time "to dig deeper into the "why' of the mathematics" (Ford 2015, p. 370). The online material created by teachers to support a blended model offers some advantages: it can easily be updated to be current and to better match student needs that arise; it can be shared among teachers to provide professional development; it gives parents a window into their children's learning (Ford 2015; Fulton 2012; Lafee 2013; Wilson 2013). 
Although implementing blended learning presents a challenge for teachers with low digital literacy (Mirriahi et al. 2015), "students continue to prefer more technologyenhanced learning experiences" (Mirriahi et al. 2015). Implementing blended learning requites offering assistance and professional development for teachers, creating opportunities for them to see the value of the affordances of blended learning (Chen et al. 2010). There also needs to be a recognition "that innovation does not happen without tension, and indeed it is tension that actually provides some of the energy that can drive innovation" (Owen and Dunham 2015 , p. 100).

In the rest of this section we report about an elementary (K-8) mathematics teacher education program at Western University in Canada developed by Gadanidis and Namukasa (2007), where a blended program has been used for the last 14 years. In the initial years, an online component was developed to replace the large lectures that accompanied smaller hands-on workshop classes, and it was noted that elementary preservice teachers came to the workshops more knowledgeable about the readings they were assigned and that they discussed online prior to the workshops. However, during the last 10 years, the focus has been on developing online mathematics-for-teachers experiences, which sometimes is done before the workshops and sometimes afterwards. The goal is to create opportunities for teachers to experience how mathematics ideas can be stretched across grades and to model mathematical connections and teaching strategies for their own teaching practice (Gadanidis and Namukasa 2007).

The mathematics-for-teachers activities are the same mathematics activities that have been developed in K-8 research classrooms for approximately a decade in Canada and in Brazil (Gadanidis and Borba 2008; Gadanidis 2012). The online component of the blended program (available at http://researchideas.ca/, see Fig. 7) serves a number of purposes: it is a form of research dissemination; it is a collection of mathematics-for-teachers activities; it is a resource freely available to teachers in the field to use in their classrooms; and it is a set of mathematics-for-teachers courses that they offer through the Fields Institute for Research in Mathematical Sciences. The online resource contains a wide variety of content:

- Classroom videos

- Mathematician interview videos

- Instructional videos

- Animations

- Simulations

- Games

- Math and coding connections

- Music videos

- E-cards.

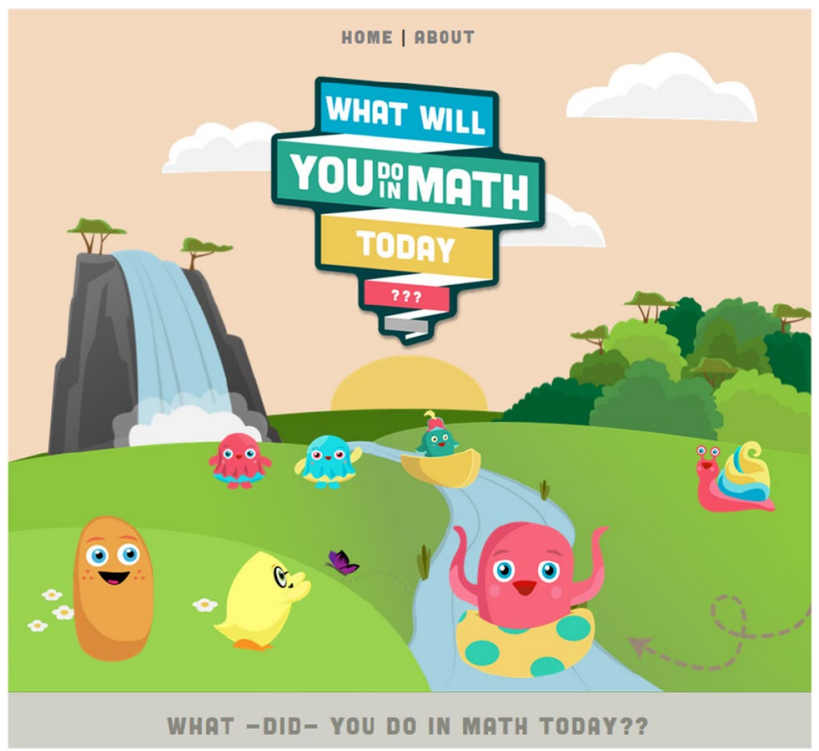

Fig. 7 Homepage of online resource

The mathematical and the pedagogical goal is to structure relationships and experiences in such a way so as to elicit mathematical surprise and insight. For example, Fig. 8a shows a grade 2 student from Brazil "performing" that "odd numbers hide in squares" and Fig. 8b shows a grade 4 student from Brazil demonstrating that "you can hold infinity in your hand."

In 2014-2015, a first draft of the online mathematicsfor-teachers resource was used with elementary pre-service teachers as a pilot study. The elementary pre-service teachers typically do not have a mathematics background, and most of them fear or dislike mathematics. As one pre-service teacher commented, "Math is not a subject I was ever very fond of". Many of the pre-service teacher comments identified the classroom videos as having an impact.

Originally when I thought of "how am I going to meet every student's need in the classroom?", I was petrified. After watching the video, I was amazed at how Iain Brodie could take a math lesson and meet the needs of all the different types of learners. Brodie's excitement is contagious.

They also commented that their beliefs of what young children can and cannot do mathematically were affected:

I now believe that actually most young children love math. I am going to try to implement what I saw in the videos when I attend practicum and discuss these ideas with my associate teacher. Maybe we can change the bad name math had been given over the years. 

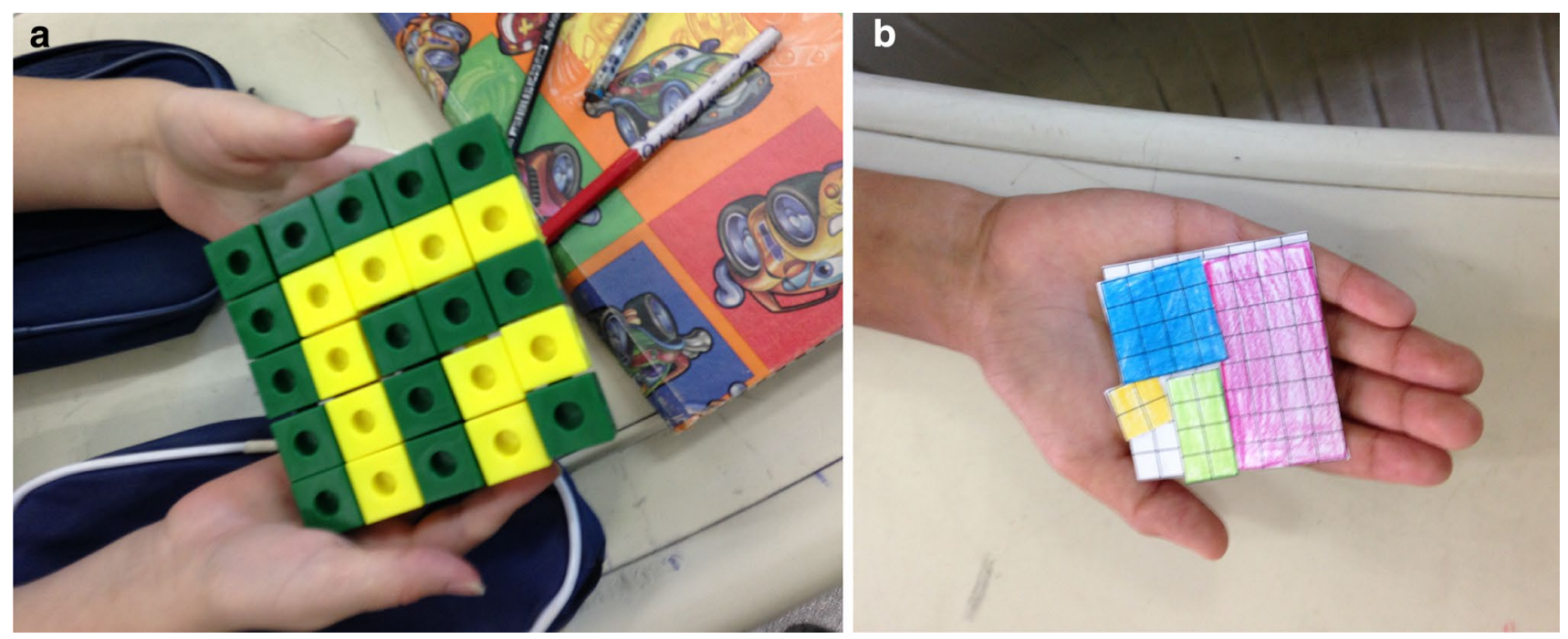

Fig. 8 a Odd numbers hide in squares. b I can hold infinity in my hand

Trouche et al. (2013) note that video and interactive multimedia cases in initial teacher-education settings allow for working collectively and reflecting on cases from mathematics classroom that show student and teacher thinking in action. The researchers also highlight that such resources offer opportunities in the field for collaborative learning of teachers in in-service settings.

In 2015-2016 this resource will be fully implemented in the blended mathematics-for-teachers program, researching how pre-service teachers use it and what they learn from using it. The researchers are especially interested in investigating how the affordances of the online resources they are creating and the structure of the online collaboration environment interact with pre-service teachers' mathematical and pedagogical thinking and learning to increase their "level of noticing" (Fernandez et al. 2012 , p. 757) through "collaborative interaction, collective argumentation and cooperative meaning-making" (Borba and Llinares 2012 p. 699). The program primarily uses asynchronous participation, and the research explores the interplay between the digital "records of teacher thinking" (Clay et al. 2012, p. 771). Goos and Geiger (2012 p. 714), exploring theoretical issues in the design and use of online mathematics learning, note that the effect of technology on collaboration and learning is not simply a matter of more learning or a greater variety of collaboration, but rather also a matter that "technology-mediated collaboration can lead to qualitatively different forms of knowledge and relationships between students, teachers, and the technology itself". Likewise, years ago Borba and Villarreal (2005), and Borba (2012), saw the individual technological and human "actors" in online mathematics teacher education as a collective that is more than the sum of its parts, whereas humans-with-media simply use think-with-technology.

\section{Conclusions and perspective}

It seems safe to say that technological change will continue and likely increase in pace. In this context, we can fall into a pattern of chasing the latest innovation rather than charting our own direction, focusing on "what is the latest technology" rather than on "what is worth researching?" Over 25 years ago, Romberg (1989, p. 254) suggested that it is important that research in mathematics education move beyond being a study of "what is" and deal more with "what ought to be," This is perhaps especially timely advice in today's rapidly changing technological landscape.

It seems reasonable to say that if this survey on digital technology and mathematics education had been developed 4 years ago for ICME 12 instead of now for ICME 13, the results would have been different. At that time, fast internet was not yet as widely available as today, and the trend toward blended learning would probably not have been as clear as it is today. Currently it seems clear that digital technology is "deconstructing" the notion of the classroom. Villarreal and Borba (2010) showed how the blackboard is no longer always present in the classroom, and how this artifact, as well as others, played an important role throughout history.

Mobile technology, PLNs, digital learning objects and other artifacts are "stretching" the classroom, transforming the classroom to the extent that it can hardly be recognized as such. A significant part of pre-service mathematics teacher education is done online in many countries 
(e.g. Brazil through Brazilian Open University, UAB; Costa Rica) in that students only meet when writing tests and a few non-mandatory face-to-face meetings (Borba and Almeida 2015; Ruiz 2013). In this scenario, the regular classroom no longer serves as locus for education. Couches, chairs, tables at students' houses, cafés and Lan Houses are the "new classrooms". Flipped classrooms change the notion of what is in and outside of the classroom and also change the roles of students and teachers.

As pointed out in the paper, PLEs and social networks such as Facebook, may make it even more difficult to keep the traditional distinction between "inside the classroom" and "outside the classroom" or between "study time" and "leisure time". Different blends are being forged into faceto-face education and online distance education in such a way that it will be interesting to see how much this distinction will be blurred by the time of ICME 2020 .

Traditionally, students completed homework and studied at dormitories or at home. The change that online learning is bringing to the way space and time surround (mathematics) education, promotes such quantitative change that it may dialectically turn into a qualitative change. Is this good or bad? We did not attempt to answer this question here. Instead, we have tried to share glimpses, that is, to open windows into what is changing in mathematics education.

The trends of development discussed in this paper highlight five important issues in the intersection of e-learning and mathematics education that might serve as contexts for investigating "what might be":

1. Student access to mobile technologies creates a student-mathematics relationship that is not yet widely embraced by mathematics educators, that disrupts the traditional flow of mathematics knowledge from teacher to student, and that is not well understood from a research perspective.

2. The potential of MOOCs to disrupt the institutional and hierarchical nature of traditional education, offering students opportunities to access courses without prerequisites, without fees (unless they require a record of course completion), and the potential of MOOCs to affect access to and the quality of mathematics education is not well understood.

3. The availability of online mathematics learning resources (as the digital libraries and learning objects) means that many students now turn to these resources before they consult a teacher or a textbook, and this raises questions about how the resources are organized in order to facilitate access and how they are designed pedagogically to foster conceptual understanding.

4. The collaborative and social networking affordances of current technologies raise questions about the design and use of LMSs as well as personal learning environments and networks.

5. Teacher use of blended learning to extend and supplement classroom learning with online exploration and discussion or to employ a flipped classroom model to make the classroom a place for extension and elaboration rather than direct instruction raises questions about the need to research the various models used.

These five themes are not independent. There are large intersections and relationships between the themes that raise cross-cutting aspects that we recognize from this review. Firstly, we notice issues related to the nature of new types of mobile/digital technological means, favouring the access to knowledge/information of mathematics and mathematics education and modifying the nature of interaction students-knowledge-teacher-context. How do we use the new technological means when the objectives are related to mathematics and mathematics education learning? Secondly, we notice issues related to how mathematics or knowledge from mathematics education is considered/organized in this new context (digital libraries, digital repertories, learning objects and inclusively the MOOCS). Finally, we identify issues related to the nature of the interaction among persons and between persons and mathematical and mathematics education knowledge when they are learning.

These three cross-cutting aspects define two dimensions in the research in this field: (1) when the focus is on how the new mobile/digital technological means define new forms of organizing knowledge and facilitating the access to knowledge (the learning objects, MOOCs, digital library, digital repository and so on), and (2) when the focus is on how the use of new mobile/digital technological means determines the nature of the interactions between humans, and between humans and knowledge in the learning contexts. So, these dimensions generate epistemological issues (about the nature of mathematical and mathematics education knowledge) and issues about social and individual aspects of learning, as well as issues about the role of interaction in this learning.

These trends that we emphasize and describe belong to the fourth phase in the development of using digital technology in mathematics education (as mentioned in the introduction). This phase is shaped by fast internet and integrated with various procedures and practices from the other three phases, as well as from the history (going back over 30 years) of attempting to include digital technology in mathematics education. Borba and Lacerda (2015) propose the idea of "one mobile phone per student" as a means of substituting campaigns such as "one computer per student". Most students have already decided that cellular phones make up part of their lives inside or outside the 
classroom. These devices are definitely part of the collective of "students-with-mobile-phones". Other technologies such as paper and pencil, as well as computer software are also accepted in this collective, but for the most part, the current generation at schools and universities do not see the world without mobile technology.

\section{References}

Aguilar, M. S., \& Puga, D. E. (2015). Mobile help seeking in mathematics: an exploratory study with Mexican engineering students. In H. Crompton \& J. Traxler (Eds.), Mobile learning and mathematics. Foundations, design, and case studies (pp. 176186). Florence, KY: Routledge.

Allen, I. E., \& Seaman, J. (2010). Learning on demand: online education in the United States, 2009. Newburyport: The Sloan Consortium.

Altun, A., \& Aşkar, P. (2008, 17-21 November). An ontological approach to designing learning objects. Paper presented at the E-Learn 2008, Las Vegas, NE, USA.

Atkins, D. E., Brown J. S., \& Hammond A.L. (2007). A review of open educational resources (OER) movement: Achievements, challenges, and new opportunities. Resource document. The William and Flora Hewlett Foundation. http://www.hewlett.org/ uploads/files/ReviewoftheOERMovement.pdf.

Attwell, G. (2007). The personal learning environments-the future of e-learning? eLearning Papers, 2(1). http://elearningeuropa. info/files/media/media11561.pdf. Accessed 7 Mar 2013.

Baki, A., \& Çakıroğlu, Ü. (2010). Learning objects in high school mathematics classrooms: implementation and evaluation. Computers \& Education, 55(4), 1459-1469. doi:10.1016/j. compedu.2010.06.009.

Bicudo, M. A. V. (2014). Meta-análise: seu significado para a pesquisa qualitativa [Meta-synthesis: its meaning in the qualitative research]. Revemat: Revista Eletrônica de Educação Matemática, 9(0), 7-20. doi:10.5007/1981-1322.2014v9nespp7.

Boaler, J. (2014). How to learn math: for teachers and parents. Resource document. Stanford University. http://online.stanford. edu/course/how-to-learn-math-for-teachers-and-parents-s14.

Borba, M. C. (2012). Humans-with-media and continuing education for mathematics teachers in online environments. ZDM-The International Journal on Mathematics Education, 44(6), 801814. doi:10.1007/s11858-012-0436-8.

Borba, M. C., \& Almeida, H. R. F. L. (2015). As licenciaturas em matemática da Universidade Aberta do Brasil (UAB): uma visão a partir da utilização das tecnologias digitais [Pre-Service Mathematics Teacher Education in "Universidade Aberta do Brasil" (Open University of Brazil): a perspective regarding the use of digital Technologies]. São Paulo: Livraria da Física

Borba, M. C., Clarkson, P., \& Gadanidis, G. (2013). Learning with the use of the Internet. In M. A. Ken Clements, A. J. Bishop, C. Keitel, J. Kilpatrick, \& F. K. S. Leung (Eds.), Third international handbook of mathematics education (pp. 691-720). New York: Springer. doi:10.1007/978-1-4614-4684-2_22.

Borba, M. C., \& Gadanidis, G. (2008). Virtual communities and networks of practising mathematics. In K. Krainer \& T. Wood (Eds.), The international handbook of mathematics teachers education. Participants in mathematics teacher education. Individual, teams, communities and networks (Vol. 3, pp. 181-206). Rotterdam/Taipei: Sense Publishers.

Borba, M. C., \& Lacerda, H. D. G. (2015). Políticas públicas e tecnologias digitais: um celular por aluno [Public Policies and Digital Technologies: a smartphone per student]. Educação Matemática Pesquisa, 17(3), 490-507.
Borba, M. C., \& Llinares, S. (2012). Online mathematics teacher education: overview of an emergent field of research. ZDM-The International Journal on Mathematics Education, 44(6), 697704. doi:10.1007/s11858-012-0457-3.

Borba, M. C., Malheiros, A. P. S., \& Zulatto, R. B. A. (2010). Online distance education (1st ed.). Rotterdam: Sense Publishers.

Borba, M. C., Scucuglia, R. R. S., \& Gadanidis, G. (2014). Fases das tecnologias digitais em educação matemática: sala de aula $e$ internet em movimento [Phases of digital technologies in mathematics education: the classroom and the Internet in motion] (1st ed.). Belo Horizonte: Autêntica.

Borba, M. C., \& Villarreal, M. E. (2005). Humans-with-Media and the reorganization of mathematical thinking. New York: Springer.

Buchem, I., Attwell, G., \& Torres, R. (2011). Understanding personal learning environments: Literature review and synthesis through the activity theory lens. Paper presented at the The PLE Conference 2011, Southampton, UK.

Candela, L. et al. (2007). The DELOS digital library reference model: foundation for digital libraries, version 0.96. Resource document. European Commission within the Sixth Framework Programme. http://delosw.isti.cnr.it/files/pdf/ReferenceModel/ DELOS_DLReferenceModel_096.pdf.

Cechinel, C., Sánchez-Alonso, S., \& García-Barriocanal, E. (2011). Statistical profiles of highly-rated learning objects. Computers \& Education, 57(1), 1255-1269. doi:10.1016/j. compedu.2011.01.012.

Chatti, A. C., Agustiawan, M. R., Jarke, M., \& Specht, M. (2010a). Toward a personal learning environment framework. International Journal of Virtual and Personal Learning Environments, 1(4), 66-85. doi:10.4018/jvple.2010100105.

Chatti, A. C., Agustiawan, M. R., Jarke, M., \& Specht, M. (2010b). The 3P learning model. Educational Technology \& Society, 13(4), 74-85.

Chen, P. D., Lambert, A. D., \& Guidry, K. R. (2010). Engaging online learners: the impact of Web-based learning technology on college student engagement. Computers \& Education, 54(4), 1222-1232. doi:10.1016/j.compedu.2009.11.008.

Clay, E., Silverman, J., \& Fischer, D. J. (2012). Unpacking online asynchronous collaboration in mathematics teacher education. ZDM-The International Journal on Mathematics Education, 44(6), 761-773. doi:10.1007/s11858-012-0428-8.

Clements, M. A. K., Bishop A. J., Keitel, C., Kilpatrick, J., \& Leung, F. K. S. (Eds.). (2013). Third international handbook of mathematics education. New York: Springer. doi:10.1007/978-1-4614-4684-2.

Clements, K., Pawlowski, J., \& Manouselis, N. (2015). Open educational resources repositories literature review-towards a comprehensive quality approaches framework. Computers in Human Behavior, 51(Part B), 1098-1106. doi:10.1016/j. chb.2015.03.026.

Coates, H., James, R., \& Baldwin, G. (2005). A critical examination of the effects of learning management systems on university teaching and learning. Tertiary Education and Management, 11(1), 19-36. doi:10.1007/s11233-004-3567-9.

Committee on Electronic Information and Communication (2014). Mathematical massive open online courses (M-MOOCs): ICM 2014 panel brief. Resource document. International Mathematical Union. http://www.mathunion.org/fileadmin/CEIC/ ICM_2014_panels/MOOCPanelBrief.pdf.

Conde, M. A., García, F. J., Alier, M., \& Casany, M. J. (2011). Merging learning management systems and personal learning environments. Proceedings of the Personal Learning Environment Conference 2011, July 2011, Southampton, UK. http://journal. webscience.org/559/. Accessed 2 Oct 2014.

Crompton, H. (2013). A historical overview of mobile learning: toward learner-centered education. In Z. L. Berge \& L. Y. 
Muilenburg (Eds.), Handbook of mobile learning (pp. 3-14). Florence: Routledge.

Crompton, H. (2015). Understanding angle and angle measure: a design-based research study using context aware ubiquitous learning. International Journal for Technology in Mathematics Education, 22(1), 19-30. doi:10.1564/tme_v22.1.02.

Crompton, H., \& Traxler, J. (Eds.). (2015). Mobile learning and mathematics. Foundations, design and case studies. Florence: Routledge.

D'Ambrosio, U., \& Borba, M. C. (2010). Dynamics of change of mathematics education in Brazil and a scenario of current research. ZDM-The International Journal on Mathematics Education, 42(3), 271-279. doi:10.1007/s11858-010-0261-x.

Daher, W. (2011). Learning mathematics in the mobile phone environment: students' emotions. Journal of Interactive Learning Research, 22(3), 357-378.

Daher, W., \& Baya'a, N. (2012). Characteristics of middle school students learning actions in outdoor mathematical activities with the cellular phone. Teaching Mathematics and Its Applications, 31(3), 133-152. doi:10.1093/teamat/hrr018.

Drexler, W. (2010). The networked student model for construction of personal learning environments: balancing teacher control and student autonomy. Australasian Journal of Educational Technology, 26(3), 369-385. doi:10.14742/ajet.v26i3.1081.

Du, C. (2011). A comparison of traditional and blended learning in introductory principles of accounting course. American Journal of Business Education, 4(9), 1-10. doi:10.19030/ajbe.v4i9.5614.

Engelbrecht, J., \& Harding, A. (2005a). Teaching undergraduate mathematics on the Internet. Part 1: technologies and taxonomy. Educational Studies in Mathematics, 58(2), 235-252. doi:10.1007/s10649-005-6456-3.

Engelbrecht, J., \& Harding, A. (2005b). Teaching undergraduate mathematics on the Internet. Part 2: attributes and possibilities. Educational Studies in Mathematics, 58(2), 253-276. doi:10.1007/s10649-005-6457-2.

Fernandez, C., Llinares, S., \& Valls, J. (2012). Learning to notice students' mathematical thinking through on-line discussions. ZDM-The International Journal on Mathematics Education, 44(6), 747-759. doi:10.1007/s11858-012-0425-y.

Ford, P. (2015). Flipping a math content course for pre-service elementary school teachers. Primus, 25(4), 369-380. doi:10.1080/ 10511970.2014.981902.

Franklin, T., \& Peng, L.-W. (2008). Mobile math: math educators and students engage in mobile learning. Journal of Computing in Higher Education, 20(2), 69-80. doi:10.1007/ s12528-008-9005-0.

Fulton, K. (2012). 10 reasons to flip. Phi Delta Kappan, 94(2), 20-24. doi:10.1177/003172171209400205.

Gadanidis, G. (2012). Why can't I be a mathematician? For the Learning of Mathematics, 32(2), 20-26.

Gadanidis, G. (2013). Designing a Mathematics-for-All MOOC. In T. Bastiaens, \& G. Marks (Eds.), Proceedings of e-learn: World conference on e-learning in corporate, government, healthcare and higher education, 2013 (pp. 704-710). Chesapeake, VA: Association for the Advancement of Computing in Education (AACE). http://www.editlib.org/p/114923. Accessed 28 July 2015.

Gadanidis, G., \& Borba, M. (2008). Our lives as performance mathematicians. For the Learning of Mathematics, 28(1), 44-51.

Gadanidis, G., \& Namukasa, I. (2007). Mathematics-for-teachers (and students). Journal of Teaching and Learning, 5(1), 13-22.

Gadanidis, G., Sedig, K., \& Liang, H. N. (2004). Designing online mathematical investigation. Journal of Computers in Mathematics and Science Teaching, 23(3), 275-298.

García-Peñalvo, F. J., Conde, M. Á., Alier, M., \& Casany, M. J. (2011). Opening learning management systems to personal learning environments. Journal of Universal Computer Science, 17(9), 1222-1240. doi:10.3217/jucs-017-09-1222.

Goos, M., \& Geiger, V. (2012). Connecting social perspectives on mathematics teacher education in online environments. ZDMThe International Journal on Mathematics Education, 44(6), 705-715. doi:10.1007/s11858-012-0441-y.

Harding, A., \& Engelbrecht, J. (2015). Personal learning network clusters: a comparison between mathematics and computer science students. Journal of Educational Technology \& Society, $18(3), 173-184$.

Holubz, B.J. (2015). Mobilizing mathematics. Participants' perspectives on Bring Your Own Device. In H. Crompton, \& J. Traxler (Eds.), Mobile learning and mathematics. Foundations, design, and case studies (pp. 213-222). Florence, KY: Routledge.

IEEE Learning Technology Standards Committee (2002). Draft standard for learning object metadata. Resource document. IEEE. http://129.115.100.158/txlor/docs/IEEE_LOM_1484_12_1_v1_ Final_Draft.pdf. Accessed 29 Jan 2016.

Ivanova, M. (2009). From personal learning environment building to professional learning network forming. Proceedings of the 5th international conference eLearning and software for education (eLSE), issue: 01/2009, (27-32). https://adlunap.ro/else2009/ papers/1001.1.Ivanova.pdf. Accessed 29 Jan 2016.

Johnson, M., \& Liber, O. (2008). The personal learning environment and the human condition: from theory to teaching practice. Interactive Learning Environments, 16(1), 3-15. doi:10.1080/10494820701772652.

Keller, J. H., Hassell, J. M., Webber, S. A., \& Johnson, J. N. (2009). A comparison of academic performance in traditional and hybrid learning in a graduate accounting course: student satisfaction and course design issues. Journal of Accounting Education, 27(3), 147-154. doi:10.1016/j.jaccedu.2010.03.001.

Kilde, J., \& Gonzales, L. (2015). A connective MOOC for k-12 science and mathematics teacher professional development in native American Pueblo schools. ICTD'15: Proceedings of the seventh international conference on information and communication technologies and development. doi: $10.1145 / 2737856.2737871$

Kinshuk, D., Jesse, R. (2013). Mobile authoring of open educational resources as reusable learning objects. The International Review of Research in Open and Distributed Learning, 14(2), 28-52.

LaFee, S. (2013). Flipped learning. The Education Digest, November Issue, 13-18.

Lalonde, C. (2012). How important is Twitter in your personal learning network? eLearn Magazine. September 2012. http://elearnmag. acm.org/featured.cfm?aid=2379624. Accessed 1 Aug 2015.

Larkin, K., \& Calder, N. (2015). Mathematics education and mobile technologies. Mathematics Education Research Journal,. doi:10.1007/s13394-015-0167-6.

Lave, J., \& Wenger, E. (1991). Situated learning: legitimate peripheral participation. Cambridge: Cambridge University Press.

Levy, P. (1993). Tecnologias da Inteligência: O futuro do pensamento na era da informática. [Technologies of Intelligence: the future of thinking in the informatics era]. Rio de Janeiro, Brazil: Editora 34.

Llinares, S., Krainer, K., \& Brown, L. (2014). Mathematics teachers and curricula. In S. Lerman (Ed.), Encyclopedia of mathematics education (pp. 438-441). New York: Springer. doi:10.1007/978-94-007-4978-8_111.

Llinares, S., \& Olivero, F. (2008). Virtual communities and networks of prospective mathematics teachers: technologies, interactions and new forms of discourse. In K. Krainer, \& T. Wood (Eds.), The international handbook of mathematics teachers education. Volume 3. Participants in mathematics teacher education. individual, teams, communities and networks (pp. 155-179). Rotterdam/Taipei: Sense Publishers. 
Martindale, T., \& Dowdy, M. (2010). Personal learning environments. In G. Veletsianos (Ed.), Emerging technologies in distance education (177-193). Edmonton, Canada: AU Press, Athabasca University. http://www.aupress.ca/books/120177/ebook/09_ Veletsianos_2010-Emerging_Technologies_in_Distance_Education.pdf. Accessed 29 Jan 2016.

McCulloch, R., \& Rothschild, L. P. (2014). MOOCs: an inside view. Notices of the AMS, 61(8), 2-8. doi:10.1090/noti1147.

McLuhan, M. (1964). Understanding media: the extensions of man. New York: McGraw Hill.

Meletiou-Mavrotheris, M., Mavrou, K., \& Paparistodemou, E. (Eds.). (2015). Integrating touch-enabled and mobile devices into contemporary mathematics education. Hershey: IGI Global.

Milligan, C., Johnson, M., Sharples, P., Wilson, S., \& Liber, O. (2006). Developing a reference model to describe the personal learning environment. In W. Nejdl \& K. Tochtermann (Eds.), Innovative approaches for learning and knowledge sharingFirst european conference on technology enhanced learning, ECTEL 2006 (pp. 506-511). Berlin/Heidelberg: Springer.

Mirriahi, N., Alonzo, D., McIntyre, S., Kligyte, G., \& Fox, B. (2015). Blended learning innovations: leadership and change in one Australian institution. International Journal of Education and Development using Information and Communication Technology, 11(1), 4-16.

Olivier, B., \& Liber, O. (2001). Lifelong learning: The need for portable personal learning environments and supporting interoperability standards. http://wiki.cetis.ac.uk/uploads/6/67/Olivierandliber2001.doc. Accessed 3 Mar 2008.

Owen, H., \& Dunham, N. (2015). Reflections on the use of iterative, agile and collaborative approaches for blended flipped learning development. Education Sciences, 5(2), 85-105. doi:10.3390/ educsci5020085.

Palmer, P. (2014). Using iPad video evidence as a tool for reflection in primary teacher education. Research in Mathematics Education, 16(2), 206-207. doi:10.1080/14794802.2014.918341.

Paulsen, M. F. (2003). Online education and learning management systems: Global e-learning in a Scandinavian perspective. NKI Gorlaget: Oslo.

Polsani, P. R. (2003). Use and abuse of reusable learning objects. Journal of Digital Information, 3(4). http://journals.tdl.org/jodi/ article/viewArticle/89/88.

Roberts, N., \& Vänskä, R. (2011). Challenging assumptions: mobile learning for mathematics project in South Africa. Distance Education, 32(2), 243-259. doi:10.1080/01587919.2011.584850.

Roger, T., \& Johnson, D. W. (1988). Cooperative learning. Two heads learn better than one. IN CONTEXT, 18. http://www.context. org/iclib/ic18/johnson/. Accessed 13 Oct 2014.

Romberg (Chair), T. A. (1989). Curriculum and valuation standards for school mathematics. Reston: National Council of Teachers of Mathematics.

Ruiz, A. (2013). La reforma de la educación matemática en Costa Rica. Perspectiva de la praxis [The mathematics education reform in Costa Rica. Perspective of praxis]. Cuadernos de Investigación y Formación en Educación Matemática, Year 8, Special Number. http://revistas.ucr.ac.cr/index.php/cifem/ article/view/11125.

Sarasty, M. F. S., \& Fernández, M. F. B. (2015). Elgg social network software readjustment to mathematics education: a study case. Proceedings of 2015 10th Iberian conference on information systems and technologies (CISTI), 1-6. doi:10.1109/ CISTI.2015.7170434.

Schrage, M. (2001). The relationship revolution. http://web.archive. org/web/20030602025739/, http://www.ml.com/woml/forum/ relation.htm. Accessed 12 July 2008.

Sclater, N. (2008). Web 2.0, personal learning environments, and the future of learning management systems. Educause Center for
Applied Research, Research Bulletin 13. http://net.educause. edu/ir/library/pdf/erb0813.pdf. Accessed 26 July 2016.

Skovsmose, O., \& Borba, M. C. (2004). Research methodology and critical mathematics education. In P. Valero, \& R. Zevenbergen (Eds.), Researching the socio-political dimensions of mathematics education: Issues of power in theory and methodology (pp. 207-226). Dordrecht: Kluwer. doi:10.1007/1-4020-7914-1_17.

Smith, J., \& Smith, R. (2012). Screen-capture instructional technology: a cognitive tool for designing a blended multimedia curriculum. Journal of Educational Computing Research, 46(3), 207-228. doi:10.2190/EC.46.3.a.

Smith, J. G., \& Suzuki, S. (2015). Embedded blended learning within an Algebra classroom: a multimedia capture experiment. Journal of Computer Assisted learning, 31(2), 133-147. doi:10.1111/jcal.12083.

NGSS Lead States (2013). Next generation science standards: for states, by states. http://www.nextgenscience.org.

Swan, K., \& Shea, P. (2005). The development of virtual learning communities. In S. R. Hiltz \& R. Goldman (Eds.), Asynchronous learning networks: The research frontier (pp. 239-260). New York: Hampton Press.

Tabbers, H., \& Koeijer, B. (2010). Learner control in animated multimedia instructions. Instructional Science, 38(5), 441-453. doi:10.1007/s11251-009-9119-4.

The Open University (2015). New MOOC-enhancing teacher education through OER: adapting and utilising OER from TESS-India. Resource document. The Open University. http:// www.open.ac.uk/about/international-development/news/ tess-india-mooc.

Tobin, D. R. (2000). All learning is self-directed: How organisations can support and encourage independent learning. Alexandria: ASTD Press.

Toerner, G., \& Arzarello, F. (2012). Grading mathematics education research journals. EMS Newsletter, 86, 52-54.

Trouche, L., Drijvers, P., Gueudet, G., \& Sacristán, A. I. (2013). Technology-driven developments and policy implications for mathematics education. In M. A. (Ken) Clements, A. J. Bishop, C. Keitel, J. Kilpatrick, \& F. K. S. Leung (Eds.), Third international handbook of mathematics education (pp. 753-789). New York: Springer. doi:10.1007/978-1-4614-4684-2_24.

Tu, C.-H., Sujo-Montes, L., Yen, C.-J., Chan, J.-Y., \& Blocher, M. (2012). The integration of personal learning environments \& open network learning environments. TechTrends, 56(3), 13-19. doi:10.1007/s11528-012-0571-7.

van de Sande, C. (2011). A description and characterization of student activity in an open, online, mathematics help forum. Educational Studies in Mathematics, 77(1), 53-78. doi:10.1007/ s10649-011-9300-y.

Villarreal, M. E., \& Borba, M. C. (2010). Collectives of humans-withmedia in mathematics education: notebooks, blackboards, calculators, computers and... notebooks throughout 100 years of ICMI. ZDM-The International Journal on Mathematics Education, 42(1), 49-62. doi:10.1007/s11858-009-0207-3.

Wagner, J. A. (1995). Studies of individualism-collectivism: effects on cooperation in groups. Academy of Management Journal, 38(1), 152-172. doi:10.2307/256731.

White, T., \& Martin, L. (2014). Mathematics and mobile learning. TechTrends, 58(1), 64-70. doi:10.1007/s11528-013-0722-5.

Wijers, M., Jonker, V., \& Drijvers, P. (2010). MobileMath: exploring mathematics outside the classroom. ZDM-The International Journal on Mathematics Education, 42(7), 789-799. doi:10.1007/s11858-010-0276-3.

Wild, F., Kalz, M., \& Palmér, M. (Eds.). (2010). Proceedings of the 3rd Workshop on Mashup Personal Learning Environments. Barcelona, Spain. http://ceur-ws.org/Vol-638/. Accessed 14 Feb 2014. 
Wild, F., Moedritscher, F., \& Sigurdarson, S. E. (2008). Designing for change: MASH-up personal learning environments. eLearning Papers 9.

Wilson, S. (2008). Patterns of personal learning environments. Interactive Learning Environments, 16(1), 17-34. doi:10.1080/10494820701772660.

Wilson, S. G. (2013). The flipped class. A method to address the challenges of an undergraduate statistics course. Teaching of Psychology, 40(3), 193-199. doi:10.1177/0098628313487461.
Yerushalmy, M., \& Botzer, G. (2011). Guiding mathematical inquiry in mobile settings. In O. Zaslavsky, \& P. Sullivan (Eds.), Constructing knowledge for teaching secondary mathematics (pp. 191207). New York: Springer. doi:10.1007/978-0-387-09812-8_12. 